\title{
Mixing Quality Characterization in Separations Process Tanks (U)
}

by

N. M. Hassan

Westinghouse Savannah River Company

Savannah River Site

Aiken, South Carolina 29808

\section{DISCLAIMER}

\begin{abstract}
This report was prepared as an account of work sponsored by an agency of the United States Government. Neither the United States Government nor any agency thereof, nor any of their employees, makes any warranty, express or implied, or assumes any legal liability or responsibility for the accuracy, completeness, or usefulness of any information, apparatus, product, or process disclosed, or represents that its use would not infringe privately owned rights. Reference herein to any specific commercial product, process, or service by trade name, trademark, manufacturer, or otherwise does not necessarily constitute or imply its endorsement, recommendation, or favoring by the United States Government or any agency thereof. The views and opinions of authors expressed herein do not necessarily state or reflect those of the United States Government or any agency thereof.
\end{abstract}

\section{DOE Contract No. DE-AC09-89SR18035}

This paper was prepared in connection with work done under the above contract number with the U.S.

Department of Energy. By acceptance of this paper, the publisher and/or recipient acknowledges the U.S. Government's right to retain a nonexclusive, royalty-free license in and to any copyright covering this paper, along with the right to reproduce and to authorize others to reproduce all or part of the copyrighted paper. 


\section{DISCLAIMER}

Portions of this document may be illegible in electronic image products. Images are produced from the best available original document. 


\section{DISCLAIMER}

This report was prepared as an account of work sponsored by an agency of the United States Government. Neither the United States Government nor any agency thereof, nor any of their employees, makes any warranty, express or implied, or assumes any legal liability or responsibility for the accuracy, completeness, or usefulness of any information, apparatus, product, or process disclosed, or represents that its use would not infringe privately owned rights. Reference herein to any specific commercial product, process, or service by trade name, trademark, manufacturer, or otherwise does not necessarily constitute or imply its endorsement, recommendation, or favoring by the United States Government or any agency thereof. The views and opinions of authors expressed herein do not necessarily state or reflect those of the United States Government or any agency thereof.

This report has been reproduced directly from the best available copy.

Available to DOE and DOE contractors from the Office of Scientific and Technical Information, P.O. Box 62, Oak Ridge, TN 37831; prices available from (615) 576-8401.

Available to the public from the National Technical Information Service, U.S. Department of Commerce, 5285 Port Royal Road, Springfield, VA 22161. 
Keywords: Mixing quality Dispersed phase Scale-up correlation Two-phase mixture Immiscible liquids

Retention : Permanent

Classification: $\mathbf{U}$

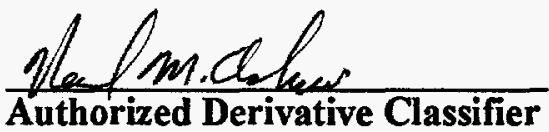

Mixing Quality Characterization in Separations Process Tanks (U)

N. M. Hassan

January 31, 1995

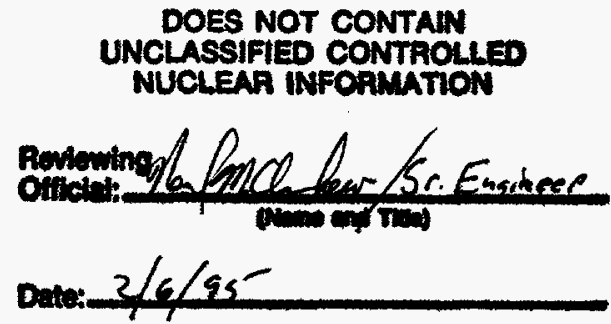

Westinghouse Savannah River Company

P. O. Box 616

Aiken, SC 29802

Prepared by the U. S. Department of Energy under Contract ICO 229486J 
Mixing Quality Characterization in Separations Process Tanks (U)

By

N. M. Hassan

Issued: January 31, 1995

\section{Approvals}

Nmblass $2-1-1995$ N. M. Hassan Author Date

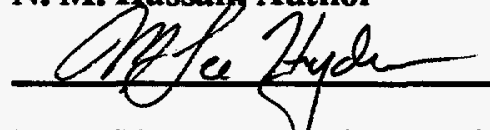

M. L. Hyder, Technical Reviewer

Date

$\sum a /$ Tren

$2-6-95$

E. A. Kyser, Technical Reviewer

Date 


\section{DISCLAIMER}

This report was prepared as an account of work sponsored by an agency of the United States Government. Neither the United. States Government nor any agency thereof, nor any of their employees, makes any warranty, express or implied, or assumes any legal liability of responsibility for the accuracy, completeness, or usefulness of any information, apparatus, product, or process disclosed, or represents that its use would not infringe privately owned rights. Reference herein to any specific commercial product, process, or service by the trade name, trademark, manufacturer, or otherwise, does not necessarily constitute or imply its endorsement, recommendation, or favoring by the United States Government or any agency thereof. The views and opinions of authors expressed herein do not necessarily state or reflect those of the United States Government or any agency thereof. 


\section{Table of Contents}

Section

Page

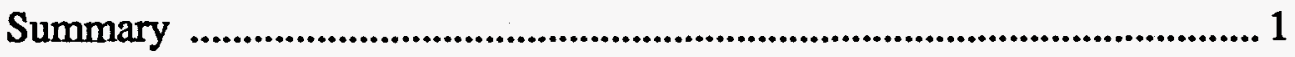

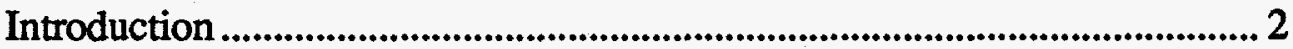

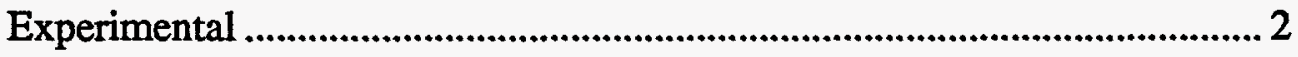

Materials and Apparatus ....................................................................... 2-3

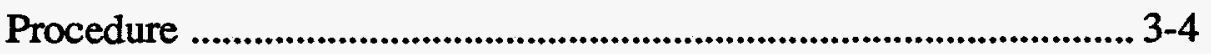

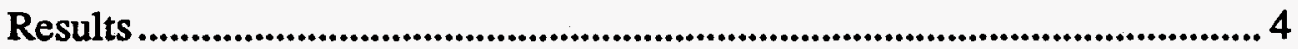

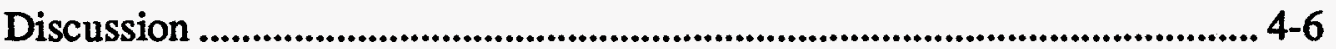

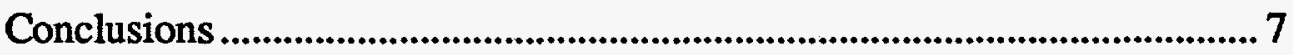

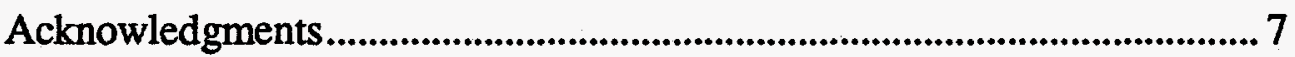

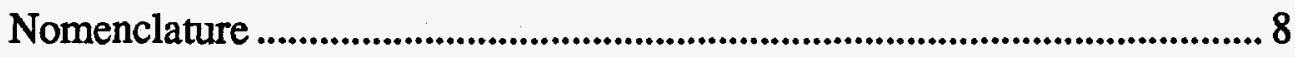

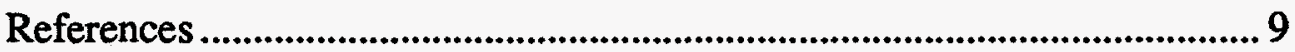

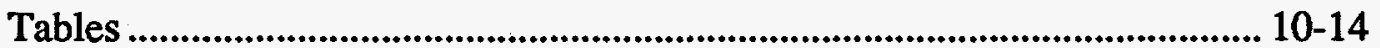

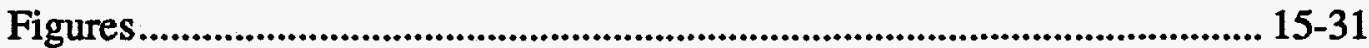




\title{
Mixing Quality Characterization in Separations Process Tanks (U)
}

\author{
by \\ N. M. Hassan \\ Westinghouse Savannah River Company \\ Savannah River Site \\ Aiken, SC 29808
}

\section{SUMMARY}

An experimental study has been performed on distribution of a dilute immiscible organic liquid dispersed in an aqueous phase contained in a baffled, paddle-agitated vessel, fitted with cooling coils. Acceptable total liquid levels in the vessel and minimum impeller speed were established for plant scale operation. Axial and radial distributions of the dispersed organic phase as functions of total liquid height, impeller speed, and the number of impellers were examined and some recurring trends were identified.

Four stages of dispersion of organic phase in predominantly aqueous phase were identified with increasing rotational speed of impeller(s). The stages were: 1) non-dispersion stage in which the organic layer was undisturbed, 2) the organic layer was decreasing with impeller speed until complete but nonuniform dispersion was attained, 3) the non-uniformity of the completely dispersed mixture decreased with increasing rotational speed of impeller(s), and 4) a grossly uniform dispersion in which the local volume fraction of dispersed phase (organic) in mixture was the same throughout the vessel.

Scale-up relationships were developed for reproducing a defined mixing quality on two geometrically similar scales of operation, for the attainable condition of complete but non-uniform dispersion. The mixing quality was observed to decrease with increasing liquid depth over acceptable range, but variations in the overall concentration of organic liquid appeared to have only slight effect on the mixing quality. 


\section{INTRODUCTION}

A problem has arisen concerning the quantitative analysis of immiscible organic liquid in a predominantly aqueous phase in baffled mixing vessels (i.e. Plant tanks), resulting from significant variation in the concentration of such compounds at different locations in the vessel. The avoidance of explosive reactions in such vessels may depend upon immiscible organic accumulations not exceeding a certain low specified value. Confidence in the attainment of this goal was clearly dependent upon how a measurement from the local sampling technique relates to concentrations elsewhere in the vessel, and on the quality of mixing prevailing under operating conditions. Clarification was therefore needed of the relation between the organic liquid concentration found at the present single sampling point, and that prevailing a maximum and average throughout the vessel.

In addition, some form of correlation was needed for reproducing a given quality of mixing-suitably defined- on both small and large scales of geometrically similar operation. This involved those variables that were capable of adjustment on the full scale; namely impeller speed $(\mathrm{N})$, height of total liquid in the vessel $(\mathrm{H})$, number of impellers (n), and dispersed (organic) phase concentration $(\bar{\phi})$. The conservative scale-up criterion of equal power input per unit volume of agitated mixture on two geometrically similar scales of operation was found to be proper for duplication of dispersed phase distributions in a predominantly aqueous phase. This approach has been used by numerous researchers (1-5) for either solid-liquid or liquid-liquid dispersions.

\section{EXPERIMENTAL}

\section{Materials and Apparatus}

The materials used in this work were deionized water employed as the continuous phase and technical grade normal paraffin hydrocarbon supplied by Exxon Chemical Company, Houston, Texas, as the dispersed (organic) phase. The normal paraffin was conservatively used instead of tributyl phosphate-nparaffin mixture (TBP/n-paraffin). The physico-chemical properties of the normal paraffin are given in Table 1 .

Figure 1 shows a schematic diagram of the experimental apparatus employed in this study. The apparatus consisted of a cylindrical, flatbottomed, Plexiglas tank, having an inside diameter (T) of 18 inches and overall height $(\mathrm{Z})$ of 36 inches. Six radial baffles of width equal to 1.25 inches were present in the tank to prevent vortex formation. Three concentric cooling coils made of 0.5 -inch diameter stainless steel tubing were mounted inside the baffles in the tank. 
Agitation was provided by a $1.8 \mathrm{HP}$ air motor with a maximum speed of $3000 \mathrm{rpm}$, and it supplied by Gast Manufacturing Corporation, Benton Harbor, Michigan. The air motor was connected to a 20-LB in-house compressed air line through a pressure regulator manufactured by ARO Corporation, Bryan, Ohio. The regulator was equipped with a pressure gauge and a filter. A lubricator was connected in the air line as close as practical to the air motor. The impellers used were two four-bladed flat-type turbines (paddles) mounted on a vertically centered shaft. The lower impeller in the flat-bottomed vessel was located at an off-bottom clearance, $C$, of 1 inch; the spacing between the blades of the upper and lower impellers, $S$, was set at an interval of 9 inches. A hand tachometer was used to measure the impeller rotational speed. The shaft, impellers, and cooling coils were all made of 304 stainless steel. All sizes of equipment were scaled down with a factor of 1:5.3 to maintain geometric similarity with 8 feet diameter $\times 11$ feet high plant tanks. Dimensions of the lab scale and plant scale equipment are listed in Table 2.

The sampling and withdrawal apparatus are shown in Figure 2. They consisted of graduated glass burettes with glass reservoirs connected on top and Teflon stopcocks on bottom. A glass manifold with two-way T-valves was located directly above glass burettes. A variable-speed Masterflex pump and stainless steel sampling tubes, each 0.25 inch in diameter, were employed to withdraw samples from designated locations identified by numerals in the schematic shown in Figure 1. The sampling tubes were inserted into the Plexiglas tank through rubber stoppers fitted into seven holes drilled in the tank cover. The tubes were located from near the bottom of the tank to top free liquid surface along the axial positions $1,3,5$, and 7 , and between the coils along radial positions 2, 4, 6, and 8. Locations between inner coils and impeller were avoided because an unbalanced impeller running at relatively high speed may endanger sampling tubes.

\section{Procedure}

There were a total of 66 experimental runs performed at various impeller speeds (N), total liquid depths $(\mathrm{H})$, and dispersed (organic) phase concentrations $(\bar{\phi})$. The predominantly aqueous phase was added into agitated vessel and the volume of dispersed and aqueous phases were adjusted in the desired proportion; the total liquid depth in the tank was adjusted to the desired level. The two-phase immiscible liquid was agitated at the desired impeller speed. After agitation was fully established, which usually occurred in less than 15 minutes, the liquid mixture from different sampling locations within the agitated vessel was circulated through the sampling tubes and back into the vessel before collecting the samples in glass burettes. A sample withdrawal velocity of $37.89 \mathrm{~cm} / \mathrm{sec}(720 \mathrm{ml} / \mathrm{min})$ was maintained throughout the sampling period to eliminate the effect of samples being separated in the tubes. 
Intermittently, the liquid mixture was diverted into glass burettes and approximately $25 \mathrm{ml}$ samples were collected from each sampling location. The samples were then allowed to separate in burettes for at least one hour, or until a clear two-phase liquid was established. The volume fractions of the dispersed (organic) and aqueous phases were measured and samples were returned to the tank. The burettes were then thoroughly cleaned with ethanol, rinsed with deionzed water, and allowed to dry before additional samples were collected. After each run, the tank was emptied and rinsed with deionized water. The desired volume proportions of the aqueous and organic phases were added into the vessel and the total liquid depth was noted and adjusted thereafter. Agitation and sampling procedures were repeated.

\section{RESULTS}

The measured values of local volume percentages of dispersed (organic) phase in the two phase mixture, $\phi$, are tabulated in Tables 3 and 4 as functions of total liquid height in the vessel $(H)$, radial position $\left(r_{0}\right)$, axial elevation above vessel floor $\left(r_{b}\right)$, impeller speed $(N)$, and a number of impellers $(n)$ at overall disperse phase concentrations $(\bar{\phi})$ of $8 \%$. These data were used to compute the local mixing quality (defined as $\eta=1$-absolute fractional deviation of the dispersed phase) at the regular single sampling denoted by $\eta_{\text {reg }}$ and the average of all measured values of $h$ denoted by $h$ ave at given levels of total liquid heights $(\mathrm{H})$ and impeller speeds $(\mathrm{N})$. The results are shown in Figures 3 and 4 corresponding to submergence of the lower impeller only, and in Figures 5 and 6 corresponding to both impellers submerged. The ratio of the ordinates of Figures 3 to 4 and 5 to 6 (i.e. $\eta_{\mathrm{reg}} / \eta_{\text {ave }}$ ) at given impeller speeds are shown in Figures 7 and 8 for single and double impellers, respectively. The measured values of local volume percentages at overall disperse phase concentrations of 4\% and 2\% are presented in Tables 5 and 6, respectively, for a fixed rotational speed of $528 \mathrm{rpm}$. These data along with appropriate data from Tables 2 and 3 are plotted in Figures 9 and 10 to examine the effect of overall of organic phase concentration on mixing quality.

\section{DISCUSSION}

The dispersion of organic phase in an immiscible aqueous phase involves a number of distinctly different stages, each of which can be reasonably well defined. The four stages of dispersion identified with increasing rotational speed of impeller (N) may be characterized in terms of the mixing quality $(\eta)$ in the schematic form sketched in Figure 11 . In stage 1 of the dispersion process, the organic layer on the top of the agitated aqueous vessel is undisturbed due to shearing influence of the low-speed impeller being insufficient to induce any dispersion. As the impeller speed is increased, the fraction of organic phase dispersed increases in stage 2 until the organic layer 
disappears and a complete but non-uniform dispersion state corresponding to $\mathrm{N}_{\text {min }}$ is reached, as described by Skelland and Seksaria (5). In stage 3 of the dispersion process, the non-uniformity of the completely dispersed mixture decreases with increasing rotational speed of the impeller. A grossly uniform dispersion is attained in stage 4 where the local volume fraction of dispersed phase is the same in samples taken throughout the vessel.

The occurrence of dispersion stages 1 to 3 , at least in the case of total liquid levels $\mathrm{H}_{2}$ to $\mathrm{H}_{6}$, was exhibited in Figures 3-6. The coils appear to contribute to the extension of stage 3 over a wide range of impeller speeds. Thus stage 4 of the dispersion process was never attained in this work, even at impeller speeds of $1000 \mathrm{rpm}$. This is consistent with the findings of Buurman et al. (6) who reported that absolute homogeneity is unattainable in practice. It should be noted that, at shallow liquid depths of $\mathrm{H}_{1}$, excessive air entrainment by the impeller interfered with the dispersion process. whereas an incomplete dispersion of the organic layer on top of the agitated aqueous phase was observed at total liquid depths of $\mathrm{H}_{7}$ and $\mathrm{H}_{8}$. Thus acceptable total liquid depths in the small scale unit are confined to the range $\mathrm{H}_{2}$ to $\mathrm{H}_{6}$ or $0.333<\mathrm{H} / \mathrm{T}<0.833$ in a geometrically similar systems. This corresponds to total liquid depths of the plant scale between 2 feet 8 inches and 6 feet and 8 inches.

Figures 3-6 also show that the lowest rotational speed of the impeller at which operation in dispersion stage 3 was always achieved was $528 \mathrm{rpm}$ for acceptable total liquid levels. Scale-up relationship based on equal power per unit volume on the two scales of operation was found to be the proper criterion. This provided an impeller speed on the plant scale of $173 \mathrm{rpm}$. Since current plant impeller speed is only $68 \mathrm{rpm}$, operation of plant scale vessel falls in the lower end of dispersion stage 2 or even in stage 1 in some case. Thus the current plant impeller speed is insufficient to completely disperse the organic layer. The scale-up criterion employed suggested that the speed should be increased roughly by 2.5 -fold, to at least $173 \mathrm{rpm}$.

Figures 7 and 8 show that the ratio $\eta_{\text {reg }} / \eta_{\text {ave }}$ at given impeller speed for single and double impellers, respectively. It is seen that at $N$ values $>400 \mathrm{rpm}$, the ratio $\eta_{\text {reg }} / \eta_{\text {ave }}$ is unity, which suggests that the value of mixing quality from the single regular sample $\left(\eta_{\mathrm{reg}}\right)$ coincides with the average of all measured values at that $H$ and $N$ values. It should noted, however, that the value of unity says nothing about the absolute mixing quality. Figures 9 and 10 show that both the mixing quality measured at the single regular sampling point and the average of that measured at all sampling locations tend to decrease with increasing liquid height between acceptable limits of $\mathrm{H}_{2}$ to $\mathrm{H}_{6}$. However, the effects of overall concentration of disperse (organic) phase on mixing 
quality are slight; the mixing quality improves slightly as the overall concentration of disperse phase, $\bar{\phi}$, decreases.

The consistencies and trends in disperse phase distribution as functions of axial and radial position, total liquid height, impeller speed, and number of impellers are exhibited in Figures 12-18. The ascending vertical heights of the sampling points above the vessel floor $\left(\mathrm{h}_{1}, \mathrm{~h}_{2}\right.$, and $\left.\mathrm{h}_{3}\right)$ and the radial locations outside $\left(r_{0}\right)$ and between the coils $\left(r_{b}\right)$ were as described in Figure 1 . The data were generally sparse throughout the vessel but a degree of consistency between the data from adjacent sets of operating conditions was observed. Thus the disperse (organic) phase concentration was usually higher outside the coils than between them. This observation was noted in the upper part of the vessel at impeller speeds 528 and $686 \mathrm{rpm}$ and for intermediate liquid levels $\mathrm{H}_{2}$ and $\mathrm{H}_{3}$ (Figures 12 and 13). This trend was reversed at high impeller speeds 844 and $1000 \mathrm{rpm}$ and persisted at all $\mathrm{N}$ values at the total liquid level $\mathrm{H}_{4}$ (Figure 14). For the vessel region outside the coils, the organic phase concentration was highest at the intermediate elevation $h_{2}$ above the vessel floor for total liquid levels $\mathrm{H}_{5}$ and $\mathrm{H}_{6}$ (Figures 15-18). The reverse distribution prevailed at $\mathrm{H}_{6}$ for the vessel region between the coils. Readers wishing to speculate on the impeller flow patterns causing these profiles may be aided by the measured velocity fields above and below a flat-blade turbine in a baffled vessel without coils, presented by McCabe and Smith (7), and in Middleton's (8).

\section{CONCLUSIONS}

The mixing quality characterization study on the lab scale unit have determined acceptable total liquid levels and minimum operable impeller speed on geometrically similar plant scale unit. The results found suggest that acceptable total liquid depths are confined to the range $0.333<\mathrm{H} / \mathrm{T}<0.833$ where $H$ is the total liquid height and $T$ is tank diameter. This corresponds to acceptable liquid levels on the plant scale between $2 \mathrm{ft}$ and 8 ins and $6 \mathrm{ft}$ and 8 ins. The current plant impeller speed was found insufficient even to completely disperse the organic layer. Scale-up relationships employing equal power per unit volume of agitated mixture on two geometrically similar scales of operation suggested a 2.5-fold increase of the plant impeller speed to at least $173 \mathrm{rpm}$ for the attainable condition of complete but non-uniform dispersion (stage 3). The disperse (organic) phase concentration profiles as functions of the total liquid level, impeller speed, and number of impellers have shown relative sparsity of the general data but somewhat a degree consistency and recurring trends between the data from adjacent sets of operating condition. This may be due to some limitations in the sampling technique. 


\section{ACKNOWLEDGMENT}

The author wishes to express his gratitude to D. A. Burge for helping to facilitate the approval of the ERDA contract with Georgia Institute of Technology, and to E. A. Kyser and T. S. Rudisill for providing helpful suggestions during the course of the experimental program. The assistance of Professor A. H. P. Skelland on experimental design and interpretation of the data is greatly acknowledged. 


\section{NOMENCLATURE}

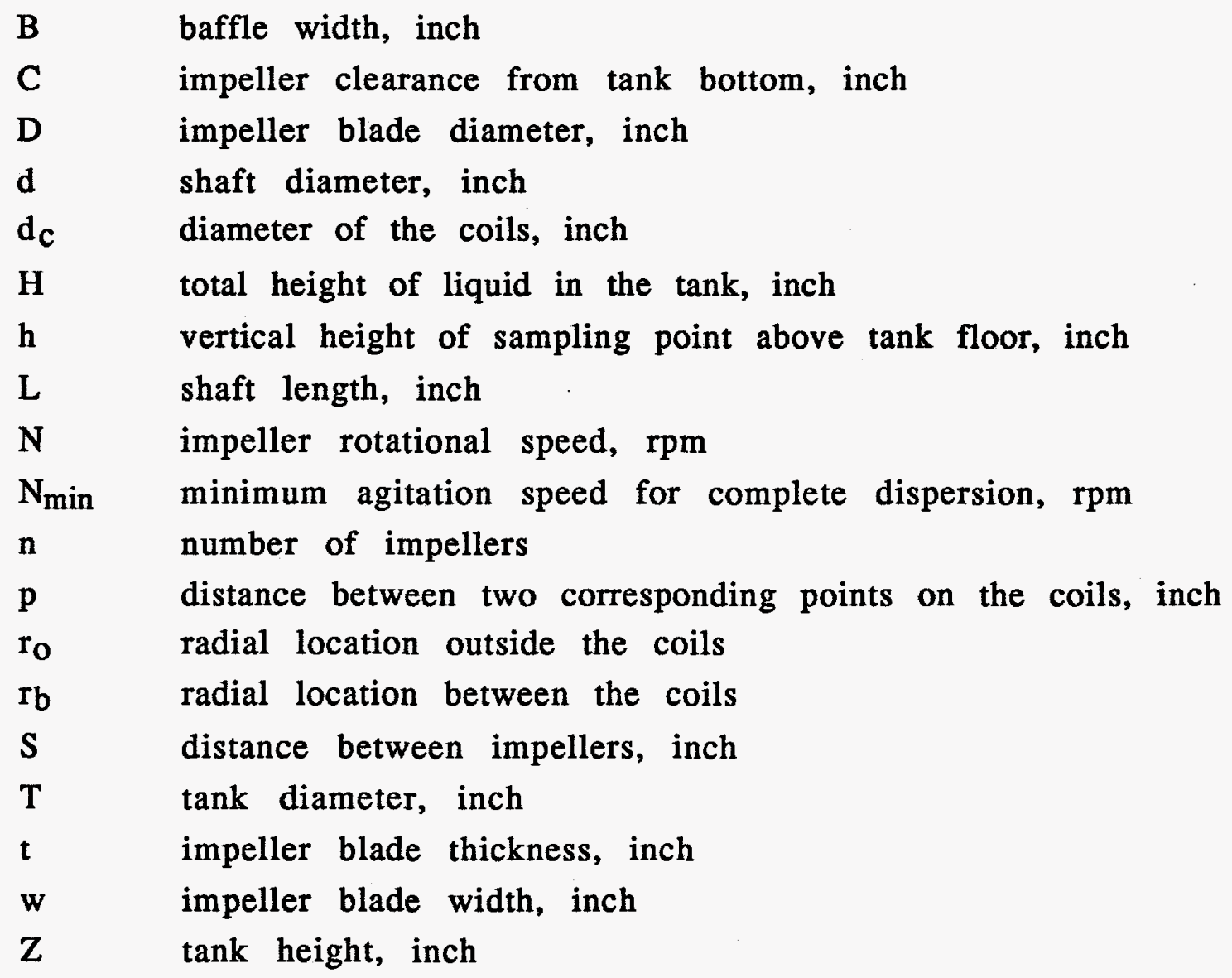




\section{REFERENCES}

1. R. E. Johnstone and M. W. Thring, Pilot Plants, Models, and Scale-up Methods in Chemical Engineering, McGraw-Hill Book, Co., New York (1957).

2. F. Rodriguez, L. C. Gratz, and D. L. Engle, "Interfacial Area in Liquid-liquid Mixing", AIChE J, 7, 663 (1961)

3. S. A. Miller and C. A. Mann, "Agitation of Two-Phase Systems of Immiscible Liquids", Trans. AIChE , 40, 709 (1944).

4. A. H. P. Skelland and G. G. Ramsay, "Minimum Impeller Speeds for Complete Liquid-Liquid Dispersion, Ind. Eng. Chem. Res 26, 77 (1987).

5. A. H. P. Skelland and R. Seksaria, "Minimum Impeller Speeds for LiquidLiquid Dispersion in Baffled Vessels, Ind. Eng. Chem. Process Des. and Dev. 17, 56 (1978).

6. C. Buurman, G. Resoort, and A. Plaschkes, "Scaling-up Rules for Solids Suspension in Stirred Vessels", Chem. Eng. Sci., 41, 2865 (1986).

7. W. L. McCabe and J. C. Smith, Unit Operations of Chemical Engineering, 2nd ed. McGraw-Hill Book, Co., New York (1967).

8. J. C. Middleton, in Mixing in Process Industries, by N. Harnby, M. F. Edwards, and A. W. Nienow, 2nd ed. Butterworth-Heinemann, Oxford (1992). 
Table 1. Physico-Chemical Properties of Normal Paraffin

\begin{tabular}{|c|c|}
\hline Property & Normal Paraffin \\
\hline Composition & \\
\hline normal paraffin, wt \% & 98 \\
\hline $\begin{array}{c}\text { aromatics, wt \% } \\
\text { olefins, wt \% }\end{array}$ & 0.2 \\
\hline Flash point, ${ }^{\circ} \mathrm{C}$ & 0.1 \\
\hline Specific gravity, @ 25/25 ${ }^{\circ} \mathrm{C}$ & 97 \\
\hline Viscosity @ 25 ${ }^{\circ} \mathrm{C}, \mathrm{cP}$ & 0.77 \\
\hline Color & 2.4 \\
\hline
\end{tabular}


Table 2. Dimensions of Lab Scale and Plant Scale Units*

\begin{tabular}{|c|c|c|c|}
\hline Unit & lab-scale tank & $\begin{array}{l}\text { plant-scale } \\
\text { tank }\end{array}$ & Remarks \\
\hline $\begin{array}{l}\text { T a n } \mathbf{k} \\
\begin{array}{l}\text { diameter, } T \\
\text { height, } Z\end{array}\end{array}$ & $\begin{array}{l}18 \\
36\end{array}$ & $\begin{array}{c}96 \\
121\end{array}$ & $\begin{array}{l}\text { plant scale tanks- } \\
8 \times 11 \text { feet vessels }\end{array}$ \\
\hline $\begin{array}{l}\text { I m p e l l e r } \\
\text { diameter, D } \\
\text { width, w } \\
\text { thickness, t } \\
\text { \# of blades } \\
\end{array}$ & $\begin{array}{l}4.5 \\
1.0 \\
0.125 \\
4 \\
\end{array}$ & $\begin{array}{c}24 \\
5 \\
0.75 \\
4\end{array}$ & $\begin{array}{l}\text { off scale by } 0.0625 \\
\text { off scale by } 0.0156\end{array}$ \\
\hline $\begin{array}{l}\text { S h a f t } \\
\begin{array}{l}\text { diameter, d } \\
\text { length, } L\end{array}\end{array}$ & $\begin{array}{c}0.625 \\
42\end{array}$ & $\begin{array}{l}3.375 \\
226\end{array}$ & \\
\hline $\begin{array}{c}\text { B affles } \\
\text { width, B } \\
\text { \# of baffles }\end{array}$ & $\begin{array}{c}1.25 \\
6\end{array}$ & $\begin{array}{l}7 \\
6\end{array}$ & $\begin{array}{c}\text { width off-scale by } \\
0.0625\end{array}$ \\
\hline $\begin{array}{l}\text { Cooling coils } \\
\text { Inner coils } \\
\text { diameter, } \mathrm{d}_{\mathrm{c}} \\
\text { pitch, } \mathrm{p}\end{array}$ & $\begin{array}{c}8 \\
0.68\end{array}$ & $\begin{array}{c}45 \\
3.625 \\
\\
60 \\
4.25 \\
\\
\\
75 \\
5.375\end{array}$ & $\begin{array}{c}7 \text { turns } \\
11 \text { turns } \\
12 \text { turns }\end{array}$ \\
\hline $\begin{array}{l}\text { Off bottom } \\
\text { clearance, } \mathrm{C} \\
\text { Distance between } \\
\text { impellers, } \mathrm{S}\end{array}$ & 1 & 6 & \\
\hline
\end{tabular}

* all dimensions are in inches 
Table 3. Local volume percentages of dispersed (organic) phase $(\bar{\phi}=8 \% ; n=1)$

\begin{tabular}{|c|c|c|c|c|c|c|c|c|}
\hline $\mathbf{N}(\mathrm{rpm})$ & $\left(h_{1}, r_{0}\right)$ & $\begin{array}{c}\phi_{2} \\
\left(h_{1}, r_{b}\right)\end{array}$ & $\begin{array}{c}\phi 3 \\
\left(h_{2}, r_{0}\right)\end{array}$ & $\begin{array}{c}\phi_{4} \\
\left(h_{2}, r_{b}\right)\end{array}$ & $\left(\begin{array}{c}\phi_{5} \\
\left(h_{3}, r_{0}\right)\end{array}\right.$ & $\begin{array}{c}\phi_{6} \\
\left(h_{3}, r_{b}\right)\end{array}$ & $\begin{array}{c}\phi_{7} \\
\left(h_{4}, r_{0}\right)\end{array}$ & $\begin{array}{c}\phi_{8} \\
\left(\mathrm{~h}_{4}, \mathrm{r}_{\mathrm{b}}\right)\end{array}$ \\
\hline $\begin{array}{c}\underline{\mathrm{H} 1} \\
207 \\
288 \\
370 \\
528 \\
686 \\
844 \\
1000\end{array}$ & $\begin{array}{l}0.7 \\
1.1 \\
5.1 \\
2.1 \\
5.4 \\
6.4 \\
5.4\end{array}$ & $\begin{array}{l}0.0 \\
0.0 \\
3.7 \\
3.3 \\
5.3 \\
6.3 \\
5.4\end{array}$ & & & & & & \\
\hline $\begin{array}{c}\underline{\mathrm{H} 2} \\
207 \\
288 \\
370 \\
528 \\
686 \\
844 \\
1000\end{array}$ & $\begin{array}{c}0 \\
3.4 \\
7.2 \\
6.9 \\
6.9 \\
8.9 \\
7.4\end{array}$ & $\begin{array}{l}0.8 \\
2.9 \\
6.3 \\
6.3 \\
6.4 \\
6.5 \\
8.1\end{array}$ & $\begin{array}{l}0.0 \\
0.0 \\
9.4 \\
7.3 \\
8.6 \\
8.2 \\
7.1\end{array}$ & $\begin{array}{l}0.0 \\
0.0 \\
6.6 \\
6.9 \\
6.7 \\
7.1 \\
6.8\end{array}$ & & & & \\
\hline $\begin{array}{c}\underline{\mathrm{H} 3} \\
207 \\
288 \\
370 \\
528 \\
686 \\
844 \\
1000\end{array}$ & $\begin{array}{l}0.0 \\
0.0 \\
2.9 \\
7.2 \\
6.9 \\
8.3 \\
8.5\end{array}$ & $\begin{array}{l}0.0 \\
0.0 \\
3.0 \\
6.3 \\
6.4 \\
7.1 \\
6.5\end{array}$ & $\begin{array}{l}0.0 \\
0.0 \\
3.1 \\
7.7 \\
7.4 \\
7.7 \\
7.1 \\
\end{array}$ & $\begin{array}{c}0.0 \\
83 \\
3.3 \\
6.5 \\
7.1 \\
7 \\
7\end{array}$ & & & & \\
\hline $\begin{array}{c}\underline{\mathrm{H} 4} \\
207 \\
288 \\
370 \\
528 \\
686 \\
844 \\
1000\end{array}$ & $\begin{array}{l}0.0 \\
0.0 \\
2.6 \\
8.3 \\
8.1 \\
8.5 \\
7.8\end{array}$ & $\begin{array}{l}0.0 \\
0.0 \\
2.6 \\
7.3 \\
7.6 \\
7.3 \\
7.5\end{array}$ & $\begin{array}{l}0.0 \\
0.0 \\
3.2 \\
7.7 \\
7.6 \\
7.4 \\
7.8\end{array}$ & $\begin{array}{c}0.0 \\
15.7 \\
3.3 \\
6.9 \\
7.4 \\
7.4 \\
7.4\end{array}$ & & & & \\
\hline
\end{tabular}


Table 4. Local Volume Percentages of Dispersed Phase $(\bar{\phi}=8 \% ; n=2)$

\begin{tabular}{|c|c|c|c|c|c|c|c|c|}
\hline$N(\mathrm{rpm})$ & $\left(\mathrm{h}_{1}, \mathrm{r}_{0}\right)$ & $\begin{array}{c}\phi_{2} \\
\left(h_{1}, r_{b}\right) \\
\end{array}$ & $\begin{array}{c}\phi 3 \\
\left(h_{2}, r_{0}\right) \\
\end{array}$ & $\begin{array}{c}\phi_{4} \\
\left(h_{2}, r_{b}\right) \\
\end{array}$ & $\left(\mathrm{h}_{3}, \mathrm{r}_{0}\right)$ & $\begin{array}{c}\phi_{6} \\
\left(h_{3}, r_{b}\right)\end{array}$ & $\begin{array}{c}\phi_{7} \\
\left(h_{4}, r_{0}\right)\end{array}$ & $\begin{array}{c}\phi_{8} \\
\left(h_{4}, r_{b}\right)\end{array}$ \\
\hline $\begin{array}{c}\mathbf{H 5} \\
207 \\
288 \\
370 \\
528 \\
686 \\
844 \\
1000 \\
\end{array}$ & $\begin{array}{l}0.7 \\
4.3 \\
5.1 \\
5.8 \\
6.6 \\
6.3 \\
6.5 \\
\end{array}$ & $\begin{array}{l}1.5 \\
4.6 \\
6.0 \\
5.8 \\
5.7 \\
7.8 \\
5.8 \\
\end{array}$ & $\begin{array}{l}2.2 \\
4.7 \\
7.3 \\
7.0 \\
8.0 \\
6.7 \\
8.0 \\
\end{array}$ & $\begin{array}{l}1.5 \\
6.0 \\
6.3 \\
6.0 \\
6.3 \\
6.7 \\
6.3 \\
\end{array}$ & $\begin{array}{l}0.0 \\
6.5 \\
6.3 \\
5.8 \\
6.0 \\
6.3 \\
6.5 \\
\end{array}$ & $\begin{array}{l}0.0 \\
5.4 \\
6.8 \\
6.8 \\
6.4 \\
6.5 \\
6.4 \\
\end{array}$ & & \\
\hline $\begin{array}{c}\underline{\mathrm{H} 6} \\
207 \\
288 \\
370 \\
528 \\
686 \\
844 \\
1000 \\
\end{array}$ & $\begin{array}{l}0.0 \\
1.1 \\
4.6 \\
4.3 \\
5.1 \\
5.8 \\
5.1 \\
\end{array}$ & $\begin{array}{l}0.0 \\
0.7 \\
3.4 \\
3.4 \\
5.7 \\
5.0 \\
5.0 \\
\end{array}$ & $\begin{array}{l}0.0 \\
1.0 \\
4.9 \\
6.0 \\
5.0 \\
6.1 \\
5.6 \\
\end{array}$ & $\begin{array}{l}0.0 \\
1.1 \\
3.7 \\
4.4 \\
4.4 \\
4.1 \\
4.8 \\
\end{array}$ & $\begin{array}{l}0.0 \\
1.4 \\
4.3 \\
4.2 \\
4.5 \\
4.7 \\
5.1 \\
\end{array}$ & $\begin{array}{l}0.0 \\
1.1 \\
4.3 \\
6.0 \\
6.0 \\
5.7 \\
5.8 \\
\end{array}$ & & \\
\hline $\begin{array}{c}\mathrm{H7} \\
207 \\
288 \\
370 \\
528 \\
686 \\
844 \\
1000 \\
\end{array}$ & $\begin{array}{l}0.0 \\
0.0 \\
0.0 \\
3.2 \\
4.6 \\
5.8 \\
4.7 \\
\end{array}$ & $\begin{array}{l}0.0 \\
0.0 \\
0.0 \\
2.9 \\
4.1 \\
5.4 \\
6.5 \\
\end{array}$ & $\begin{array}{l}0.0 \\
0.0 \\
0.4 \\
4.6 \\
4.9 \\
5.3 \\
5.7 \\
\end{array}$ & $\begin{array}{l}0.0 \\
0.0 \\
0.0 \\
3.0 \\
2.9 \\
4.0 \\
5.2 \\
\end{array}$ & $\begin{array}{l}0.0 \\
1.1 \\
0.0 \\
4.6 \\
4.9 \\
6.1 \\
5.4 \\
\end{array}$ & $\begin{array}{l}0.0 \\
0.0 \\
0.0 \\
3.5 \\
4.6 \\
5.0 \\
6.2 \\
\end{array}$ & $\begin{array}{c}78.1 \\
80.0 \\
100 \\
100 \\
9.6 \\
5.7 \\
5.6 \\
\end{array}$ & $\begin{array}{c}29.0 \\
78.5 \\
100 \\
100 \\
9.1 \\
6.3 \\
5.1 \\
\end{array}$ \\
\hline $\begin{array}{c}\frac{H 8}{207} \\
288 \\
370 \\
528 \\
686 \\
844 \\
1000 \\
\end{array}$ & $\begin{array}{l}0.0 \\
0.0 \\
0.0 \\
0.3 \\
3.9 \\
7.1 \\
6.5 \\
\end{array}$ & $\begin{array}{l}0.0 \\
0.0 \\
0.0 \\
0.4 \\
2.5 \\
6.8 \\
5.0 \\
\end{array}$ & $\begin{array}{l}0.0 \\
0.0 \\
0.0 \\
0.7 \\
4.0 \\
6.5 \\
7.2 \\
\end{array}$ & $\begin{array}{l}0.0 \\
0.0 \\
1.1 \\
0.7 \\
4.0 \\
6.5 \\
7.2 \\
\end{array}$ & $\begin{array}{l}0.0 \\
0.0 \\
0.0 \\
1.4 \\
4.7 \\
7.0 \\
6.9 \\
\end{array}$ & $\begin{array}{l}0.0 \\
0.0 \\
0.0 \\
1.4 \\
7.4 \\
6.5 \\
4.8\end{array}$ & $\begin{array}{l}1.8 \\
0.0 \\
0.0 \\
1.9 \\
3.2 \\
6.3 \\
6.0 \\
\end{array}$ & $\begin{array}{l}2.1 \\
0.4 \\
0.7 \\
3.0 \\
4.4 \\
6.2 \\
5.7\end{array}$ \\
\hline
\end{tabular}


Table 5. Local Volume Percentages of Dispersed Phase (N=528 rpm)

\begin{tabular}{|c|c|c|c|c|c|c|c|c|}
\hline & $\begin{array}{c}\phi_{1} \\
\left(h_{1}, r_{0}\right)\end{array}$ & $\begin{array}{c}\phi_{2} \\
\left(\mathrm{~h}_{1}, \mathrm{r}_{\mathrm{b}}\right)\end{array}$ & $\begin{array}{c}\phi 3 \\
\left(h_{2,} r_{0}\right)\end{array}$ & $\begin{array}{c}\phi_{4} \\
\left(\mathrm{~h}_{2}, \mathrm{r}_{\mathrm{b}}\right)\end{array}$ & $\begin{array}{c}\phi_{5} \\
\left(\mathrm{~h}_{3}, \mathrm{r}_{\mathrm{o}}\right)\end{array}$ & $\begin{array}{c}\phi_{6} \\
\left(h_{3}, r_{b}\right)\end{array}$ & $\begin{array}{c}\phi_{7} \\
\left(h_{4}, r_{0}\right)\end{array}$ & $\begin{array}{c}\phi_{8} \\
\left(h_{4}, r_{b}\right)\end{array}$ \\
\hline $\begin{array}{l}\bar{\phi}=8 \% \\
\text { n1H2 } \\
\text { n1 H3 } \\
\text { n1H4 } \\
\text { n2H6 } \\
\text { n2H8 }\end{array}$ & $\begin{array}{l}6.9 \\
7.2 \\
8.3 \\
4.3 \\
0.3\end{array}$ & $\begin{array}{l}6.3 \\
6.3 \\
7.3 \\
3.4 \\
0.4\end{array}$ & $\begin{array}{l}7.3 \\
7.7 \\
7.7 \\
6.0 \\
0.7\end{array}$ & $\begin{array}{l}6.9 \\
6.5 \\
6.9 \\
4.4 \\
0.7\end{array}$ & $\begin{array}{l}4.2 \\
1.4\end{array}$ & $\begin{array}{l}6.0 \\
1.4\end{array}$ & 1.9 & 3.0 \\
\hline $\begin{array}{l}\bar{\phi}=4 \% \\
\text { n } 1 \mathrm{H} 2 \\
\text { n1 } 13 \\
\text { n } 1 \mathrm{H} 4 \\
\text { n2H6 } \\
\text { n2H8 }\end{array}$ & $\begin{array}{l}3.6 \\
3.2 \\
3.3 \\
2.5 \\
0.4\end{array}$ & $\begin{array}{l}3.1 \\
3.4 \\
3.0 \\
1.9 \\
0.4\end{array}$ & $\begin{array}{l}3.3 \\
3.6 \\
3.3 \\
0.7\end{array}$ & $\begin{array}{l}2.8 \\
2.5 \\
2.1 \\
1.0\end{array}$ & $\begin{array}{l}2.1 \\
0.7\end{array}$ & $\begin{array}{l}3.2 \\
0.7\end{array}$ & 1.1 & 1.4 \\
\hline $\begin{array}{l}\bar{\phi}=2 \% \\
\text { n1H2 } \\
\text { n } 1 \text { H3 } \\
\text { n1H4 } \\
\text { n2H6 } \\
\text { n2H8 }\end{array}$ & $\begin{array}{l}1.8 \\
1.8 \\
1.8 \\
1.4 \\
0.7\end{array}$ & $\begin{array}{l}1.9 \\
2.3 \\
1.9 \\
1.5 \\
0.4\end{array}$ & $\begin{array}{l}2.2 \\
1.9 \\
1.9 \\
1.8 \\
0.7\end{array}$ & $\begin{array}{l}2.4 \\
2.1 \\
1.8 \\
1.8 \\
0.3\end{array}$ & $\begin{array}{l}1.7 \\
0.4\end{array}$ & $\begin{array}{l}1.8 \\
0.4\end{array}$ & 0.7 & 0.7 \\
\hline
\end{tabular}

$n=1$ (one impeller submerged in the liquid), $n=2$ (two impellers submerged in the liquid) 


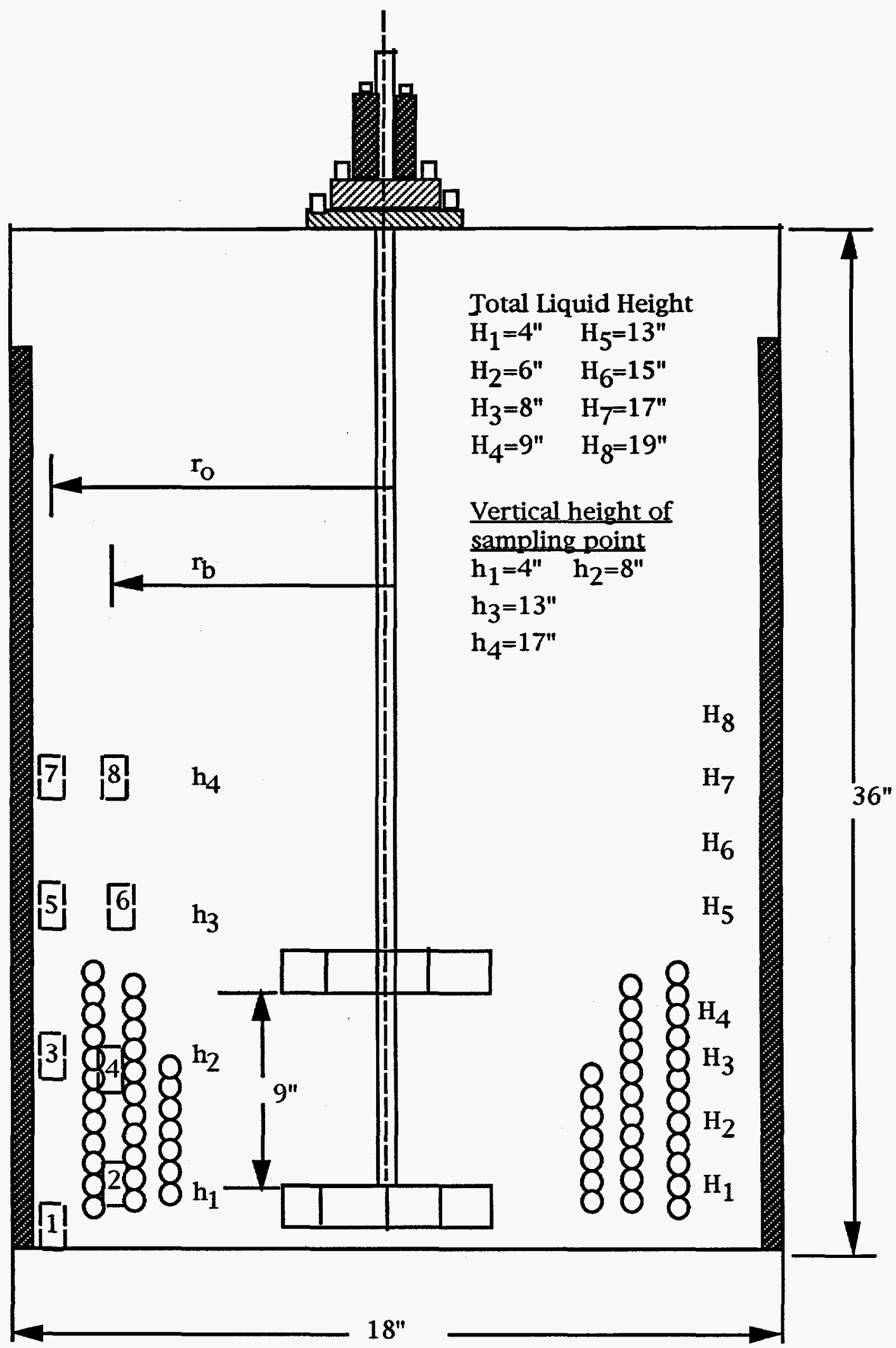

Figure 1. Schematic diagram of the experimental apparatus 


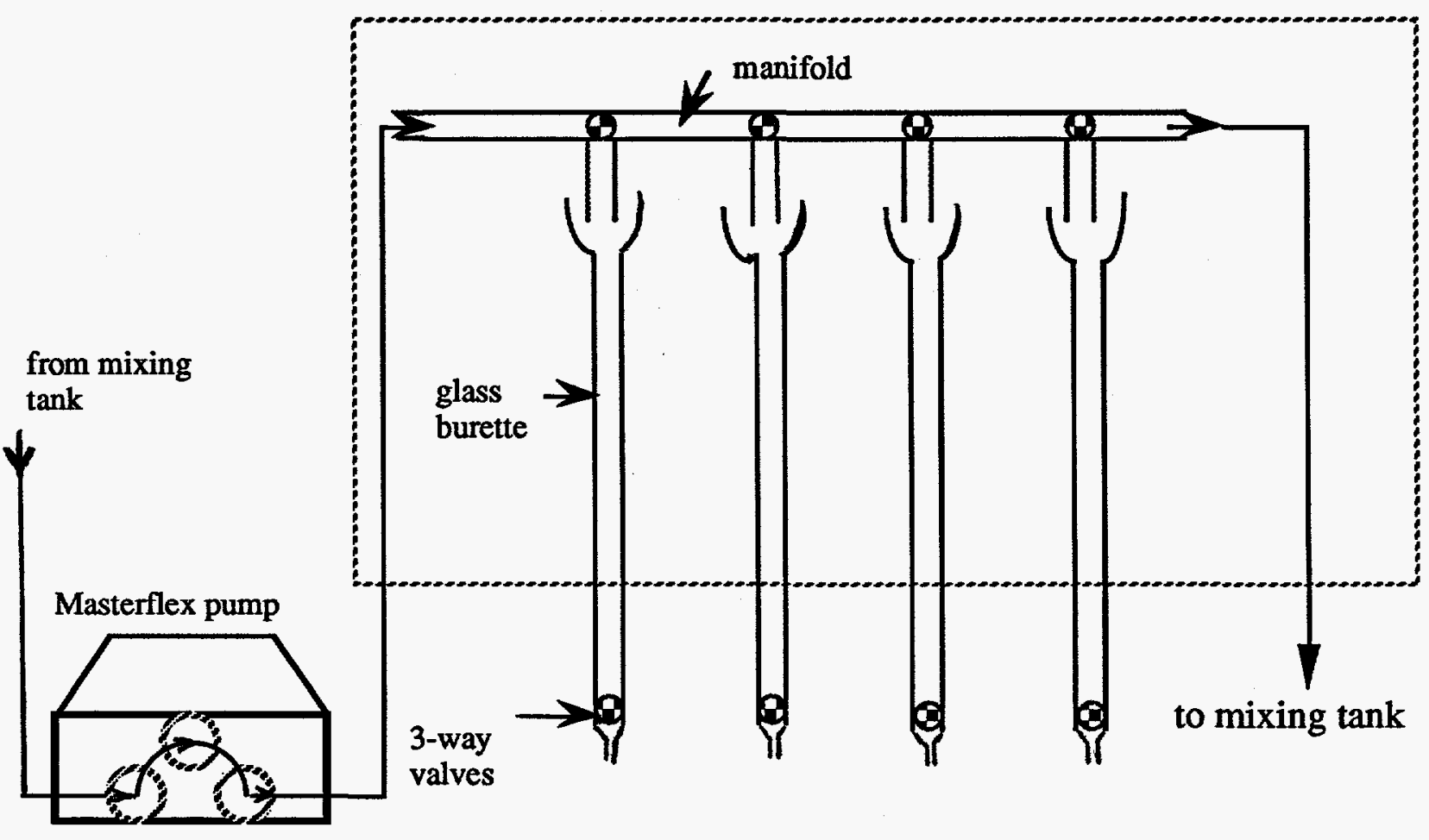

Figure 2. Schematic diagram of the sampling 


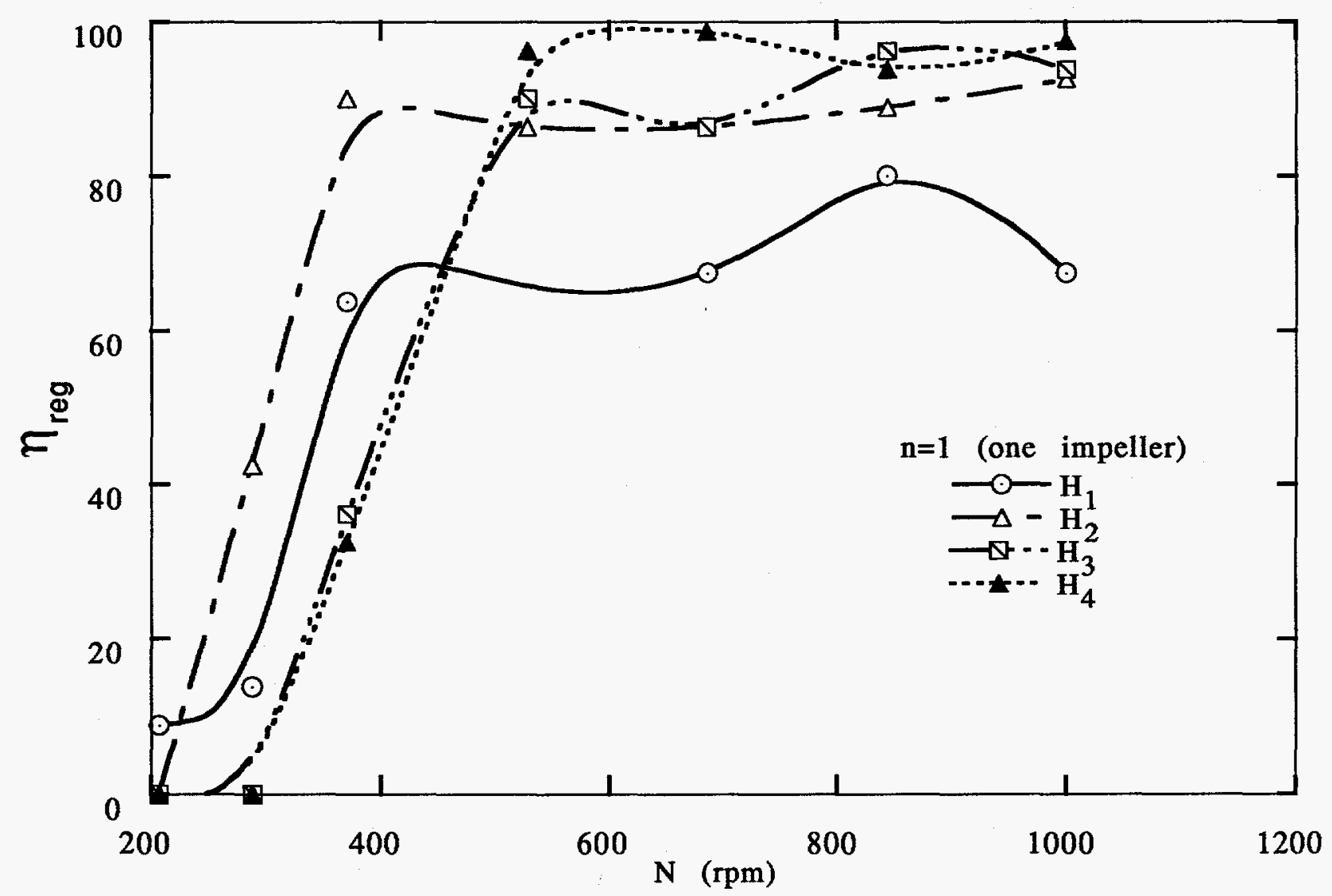

Figure 3. The local mixing quality at the regular single sampling location as a function of impeller speed. 


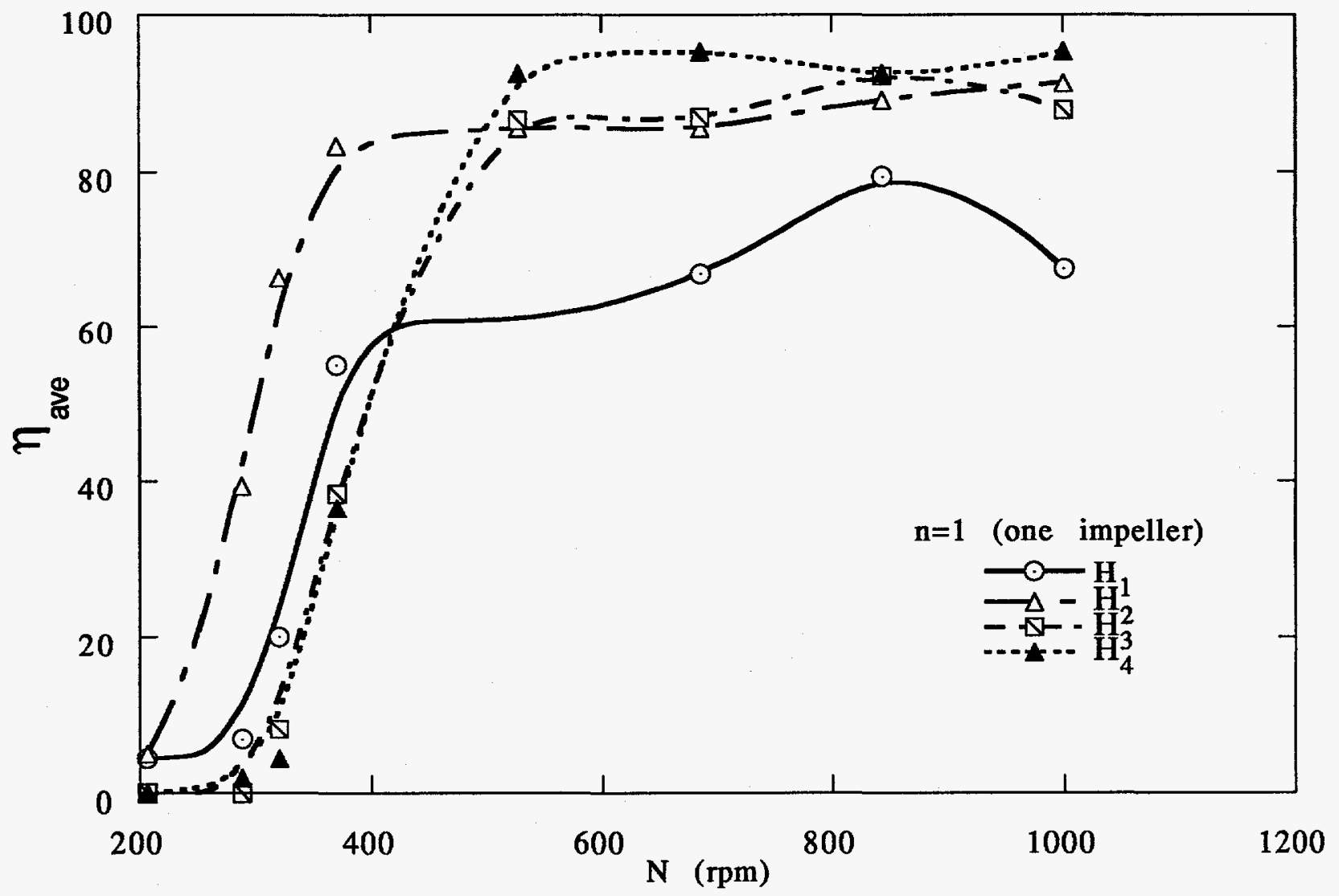

Figure 4. The mixing quality average from all sampling locations as a function of impeller speed. 


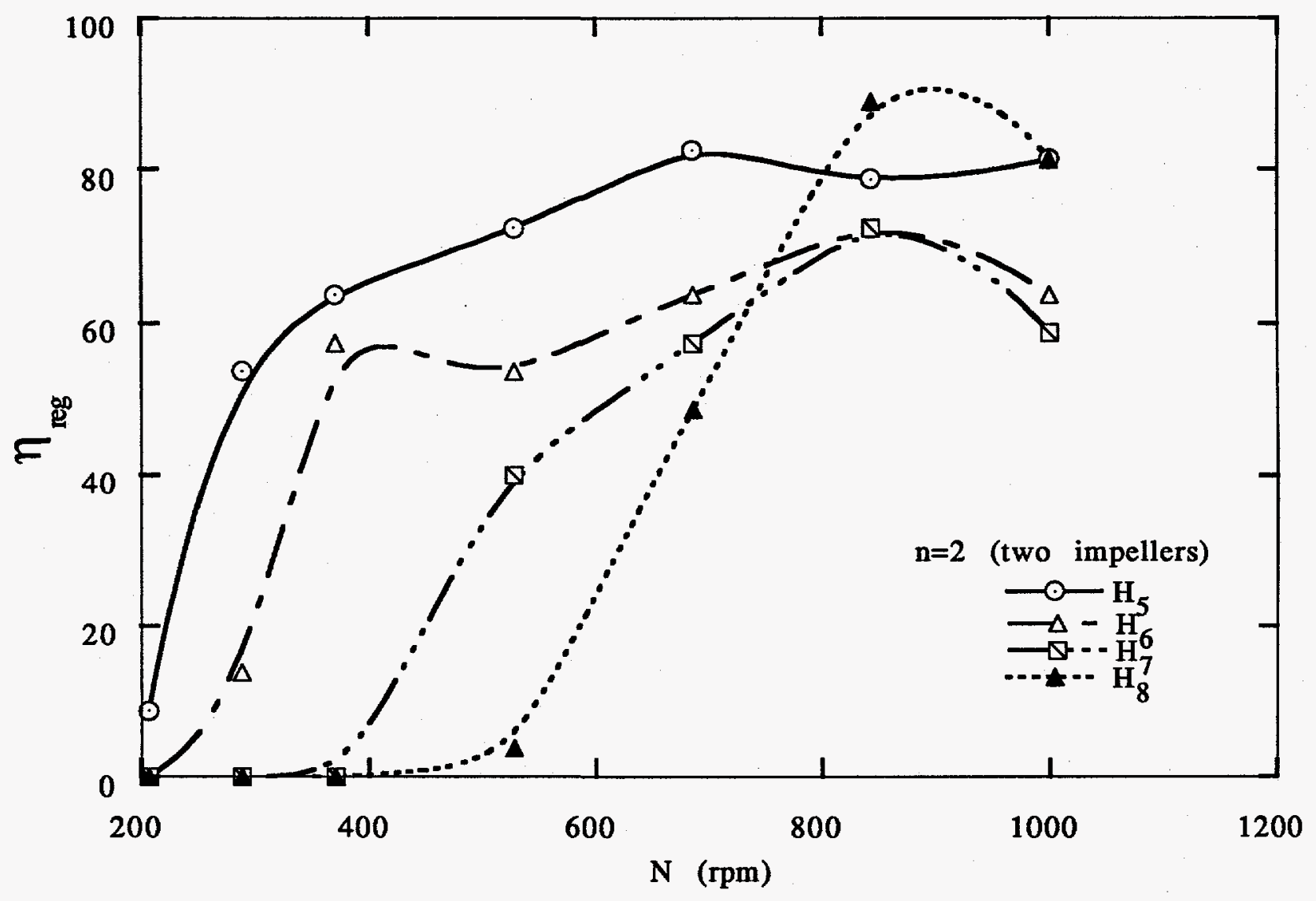

Figure 5. The local mixing quality at the regular single sampling location as a function of impeller speed 


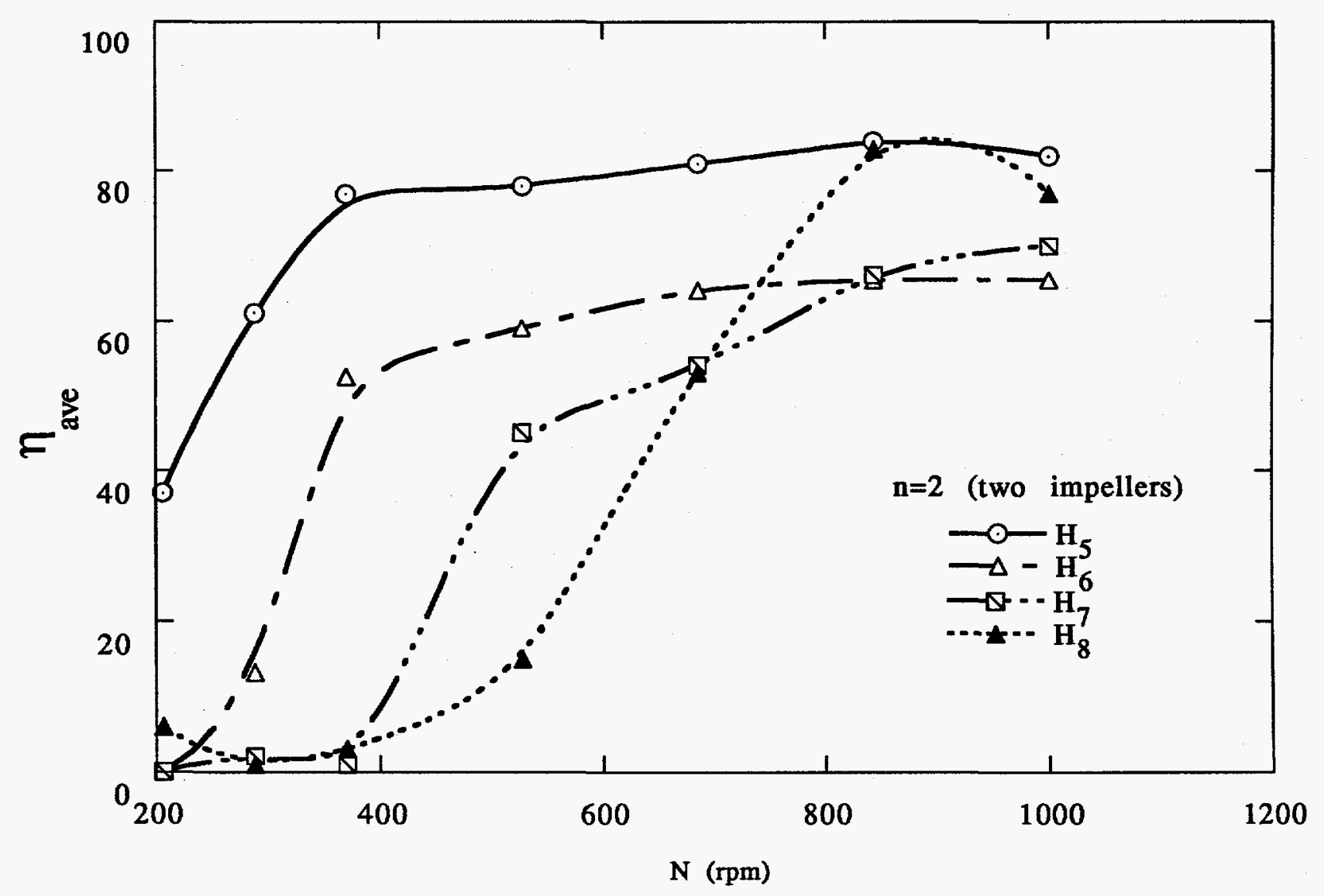

Figure 6. The mixing quality average from all sampling locations as a function of impeller speed. 


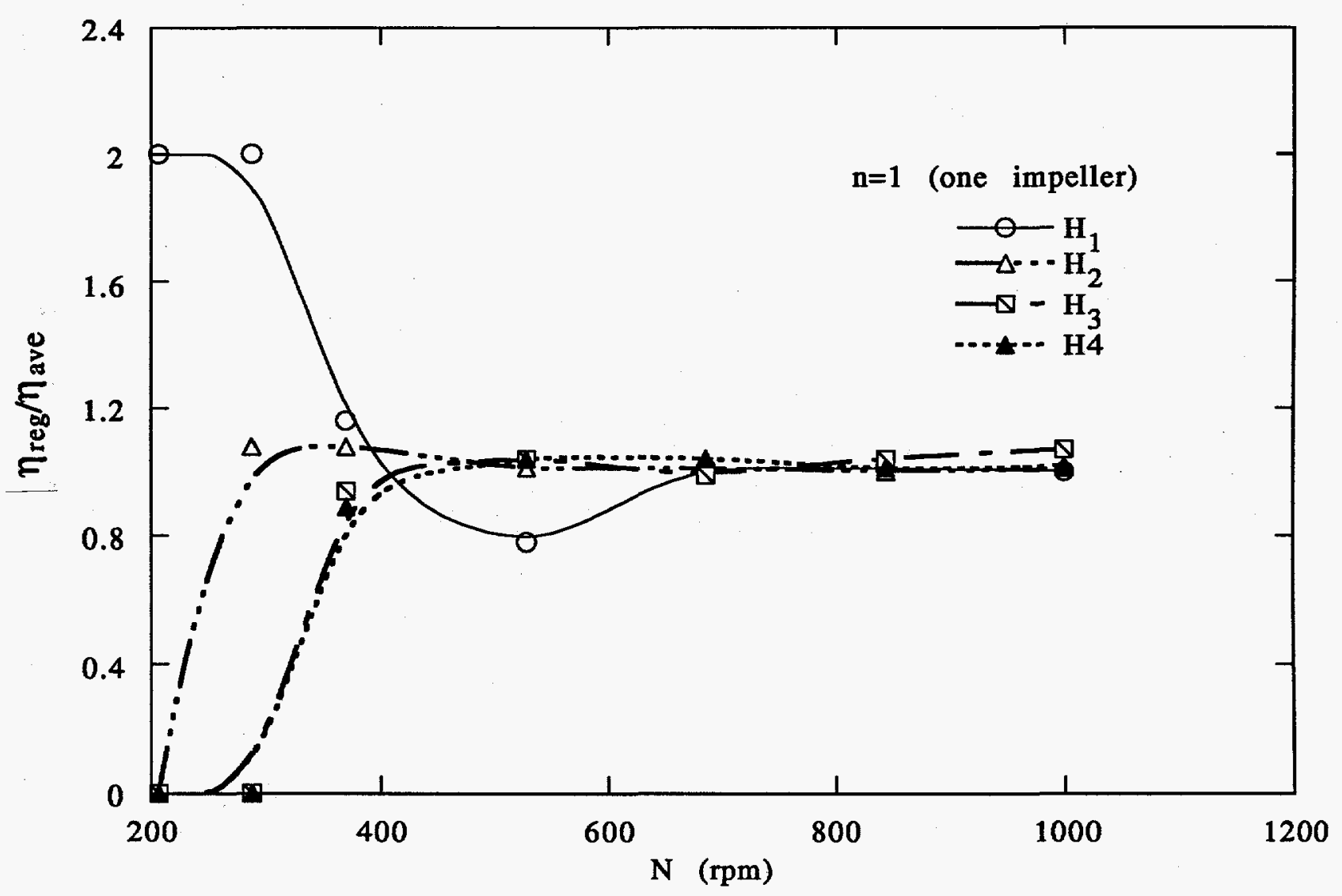

Figure 7. The mixing quality ratio of the regular single sampling location to the average from all sampling locations as a function of impeller speed. 


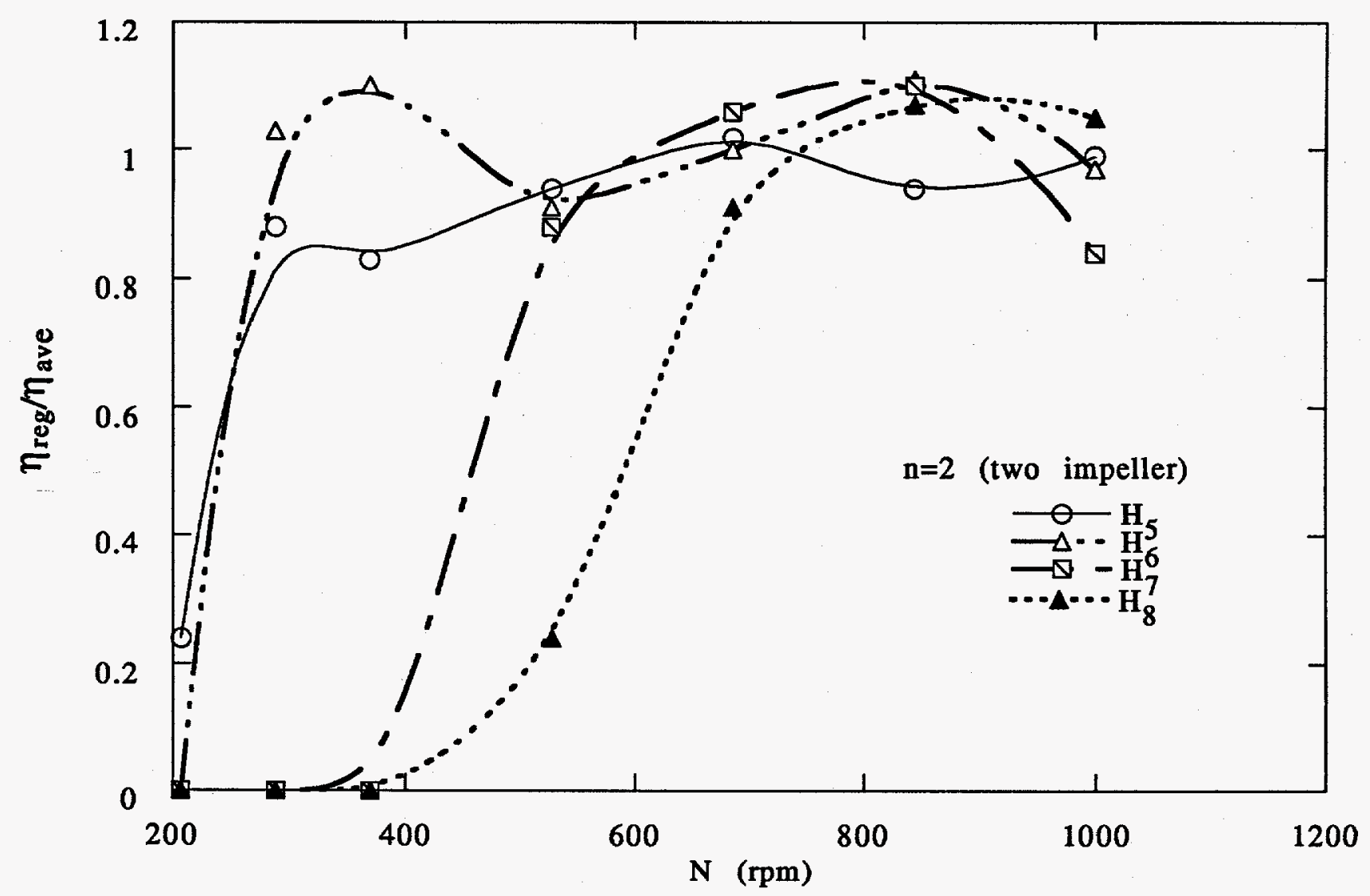

Figure 8. The mixing quality ratio of the regular single sampling location to the average from all sampling locations as a function of impeller speed. 


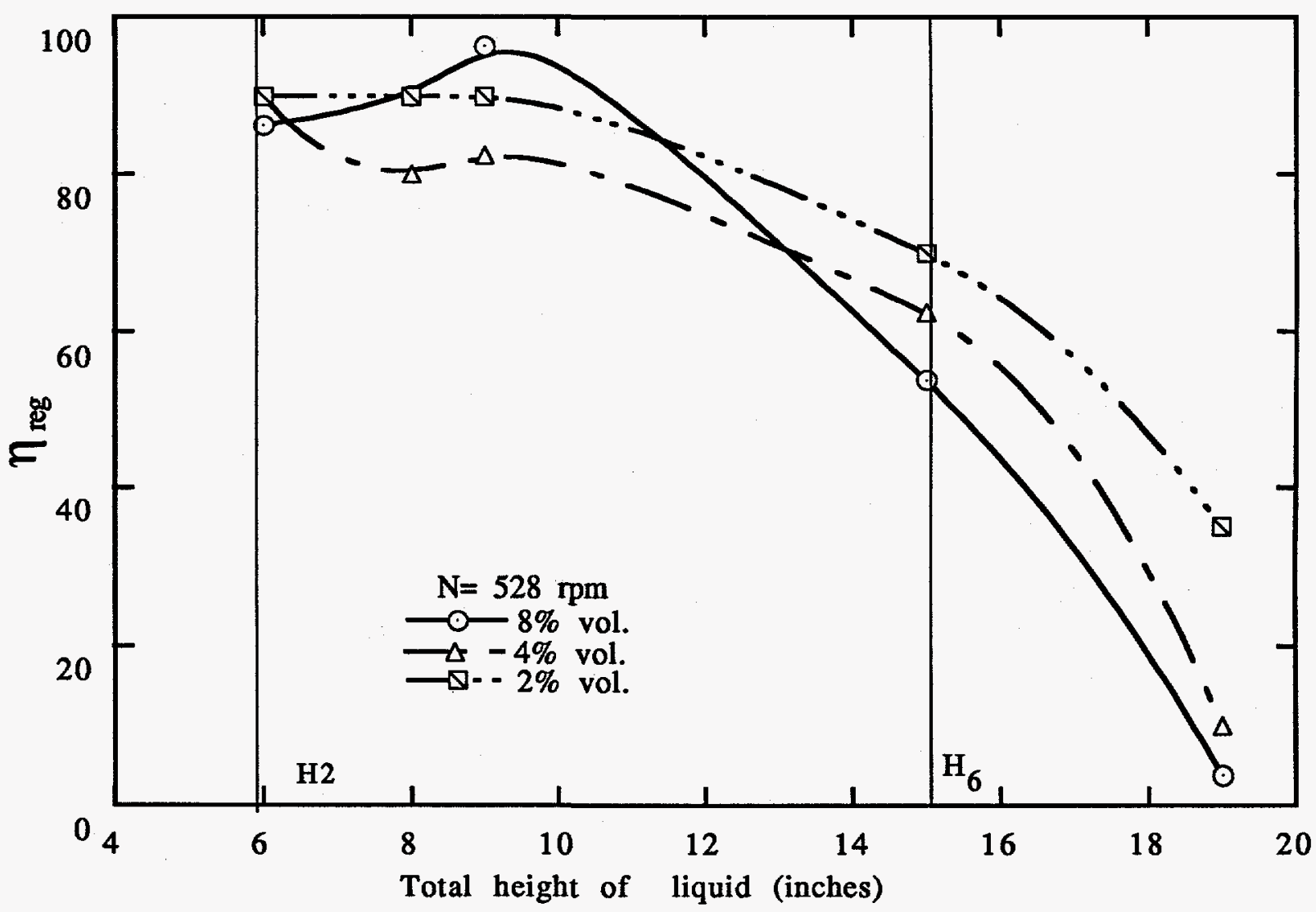

Figure 9. The mixing quality at the regular single sampling location as a function of total liquid height 


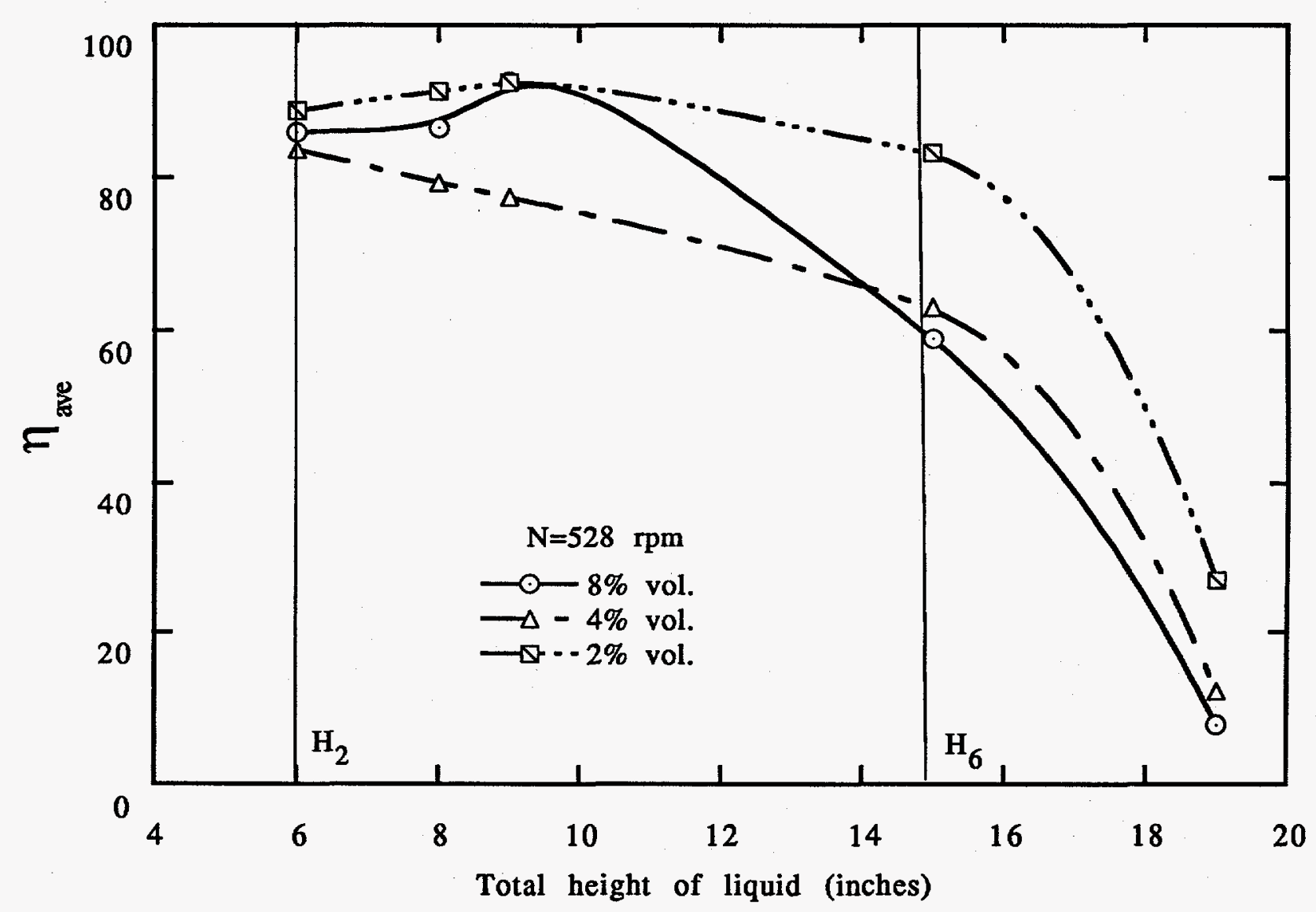

Figure 10. The mixing quality average from all sampling locations as a function of total liquid height. 


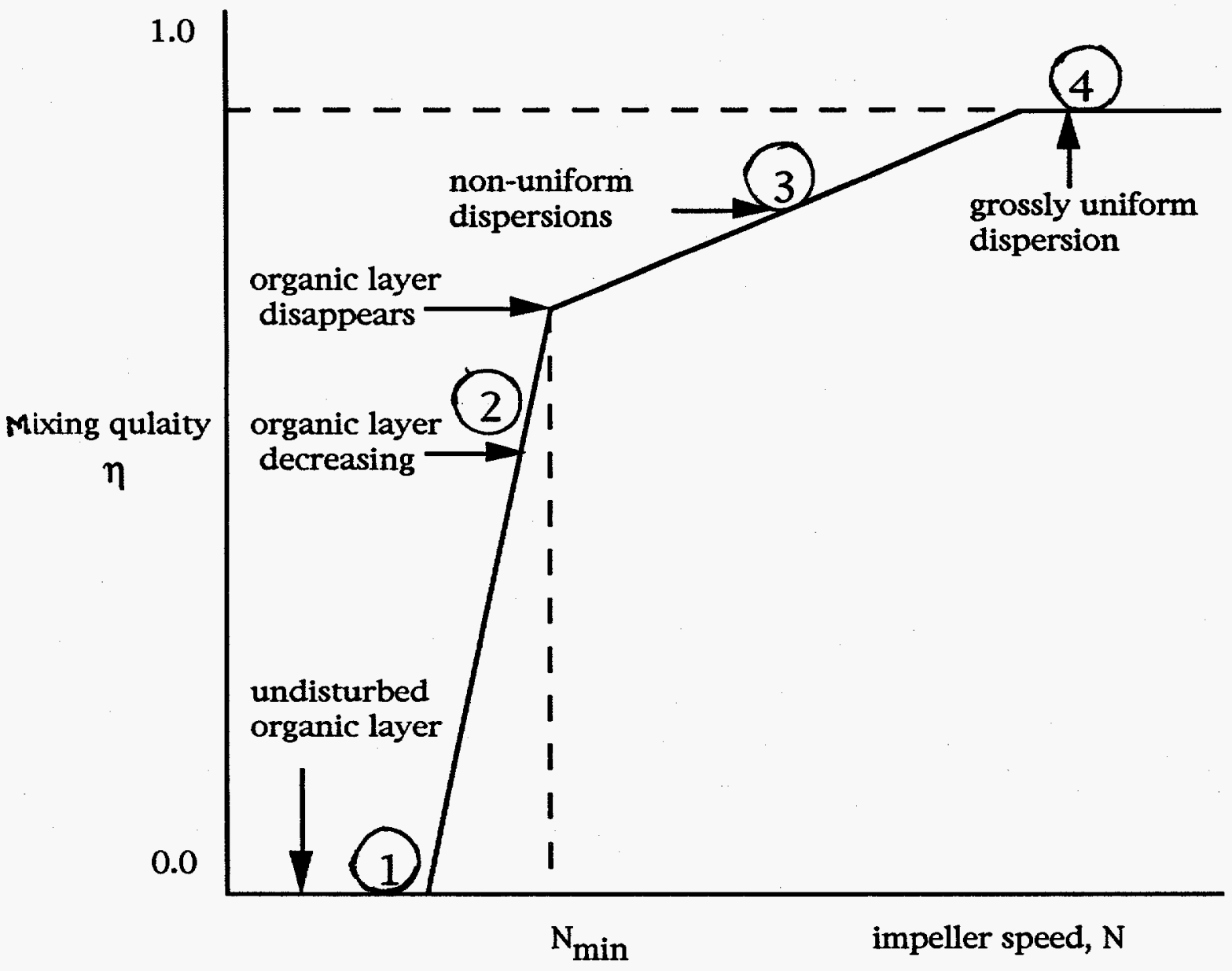

Figure 11. A schematic diagram of the effect of impeller speed on stages of dispersion in immiscible liquid-liquid systems. 


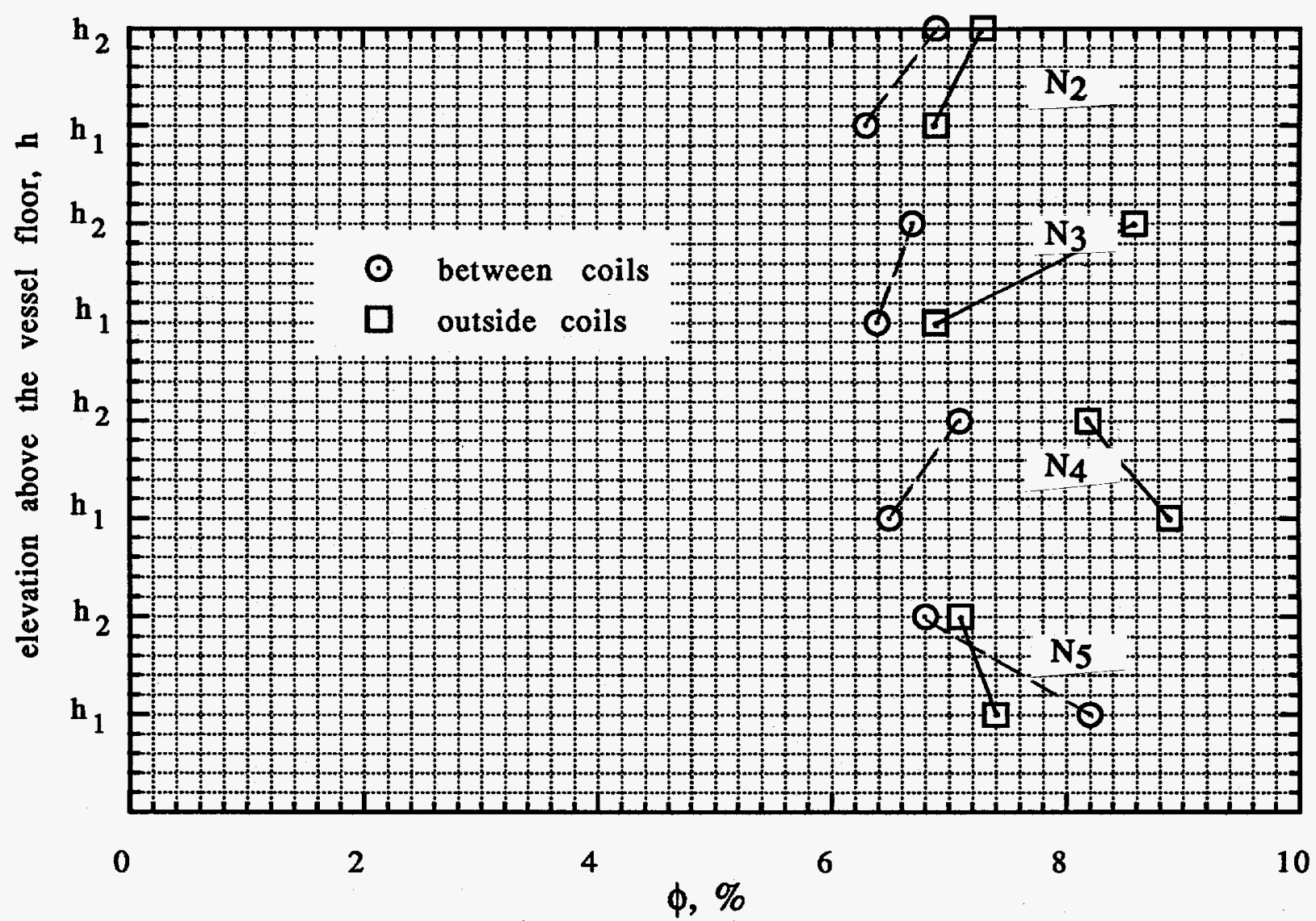

Figure 12. Axial and radial profiles for the organic phase with one impeller as functions of elevation $h$ and radial positions at total liquid depth $\mathrm{H} 2$ and impeller speeds 528, 686, 844, and $1000 \mathrm{rpm}$. 


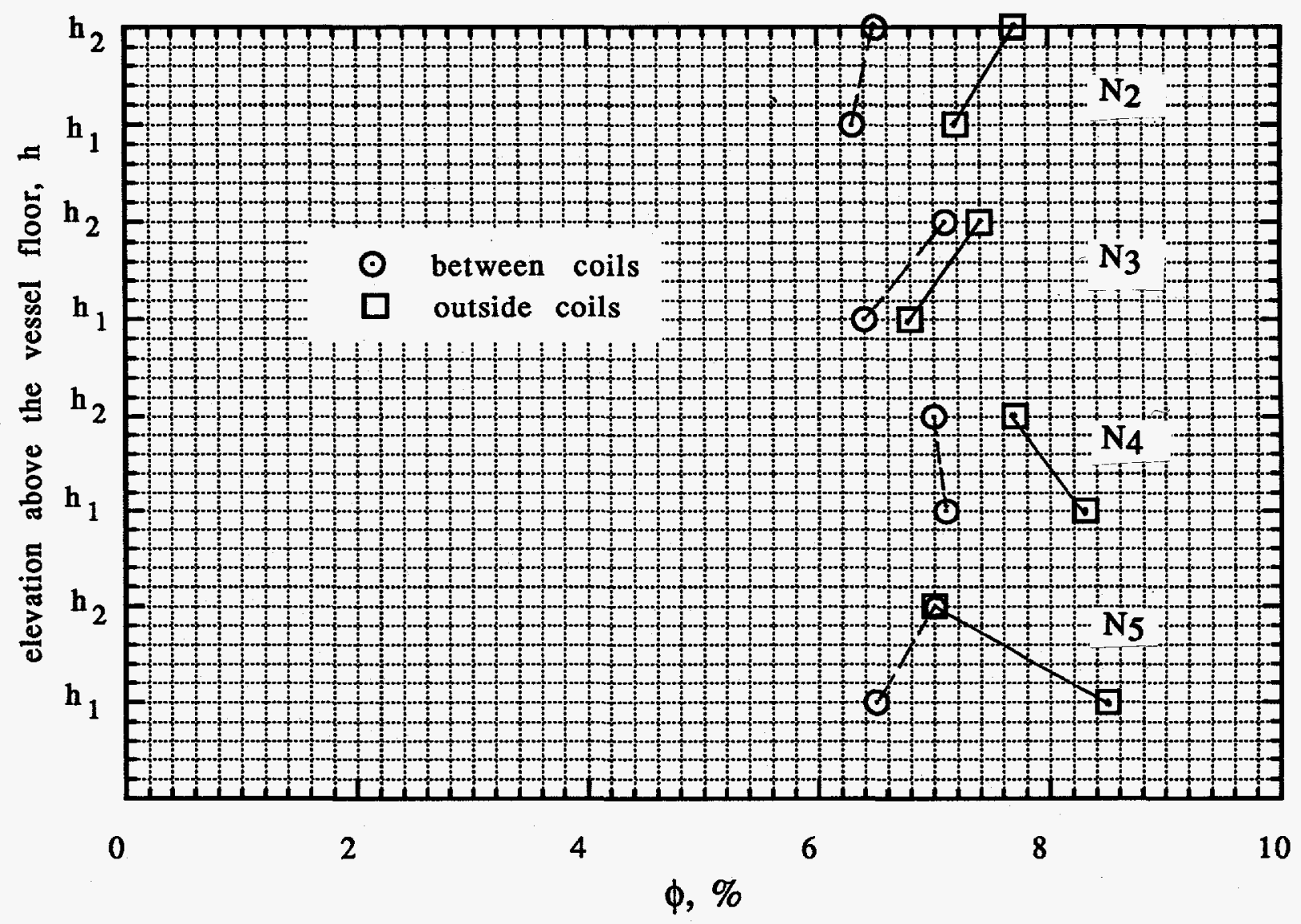

Figure 13. Axial and radial profiles for the organic phase with one impeller as functions of elevation and radial positions at total liquid depth $\mathrm{H} 3$ and impeller speeds 528, 686, 844, and $1000 \mathrm{rpm}$. 


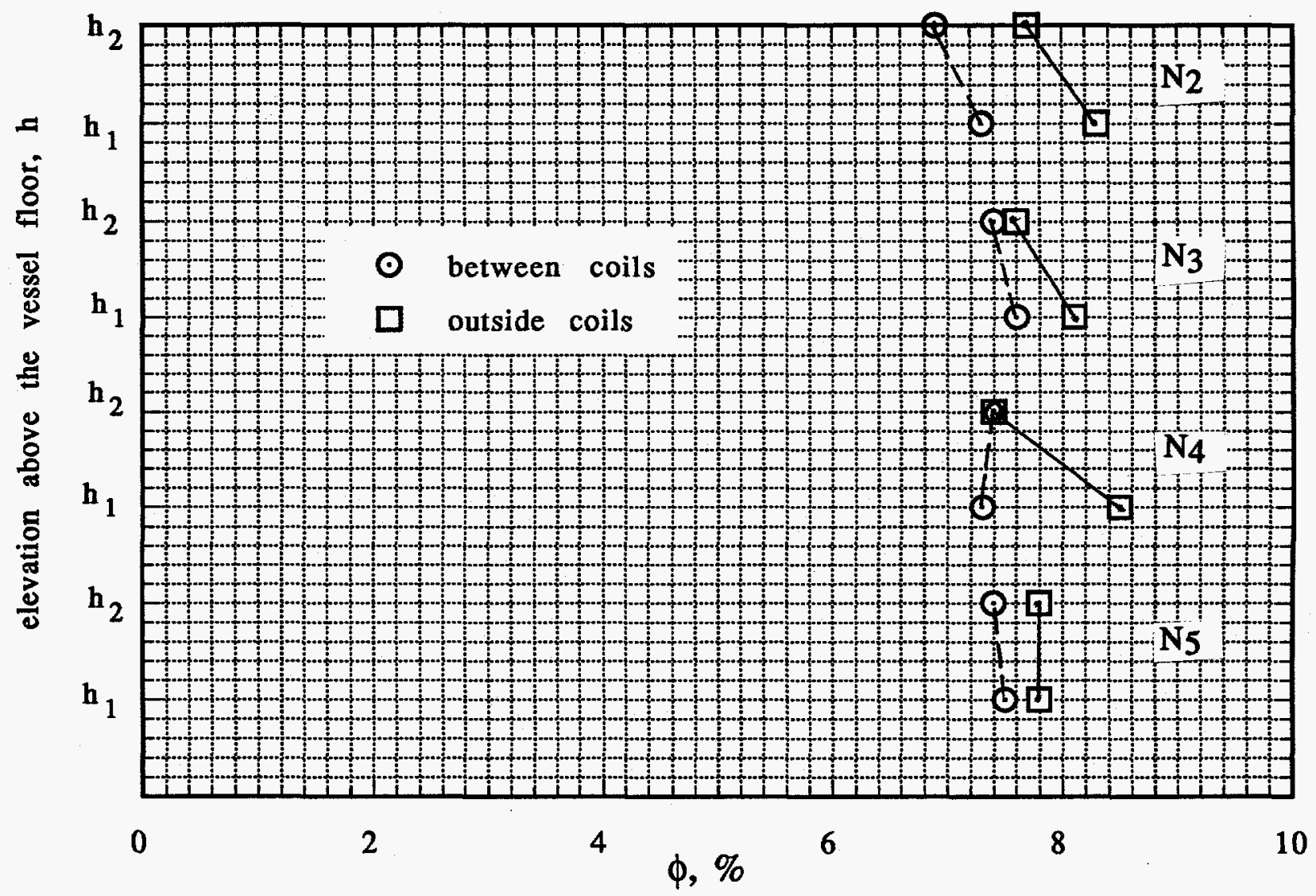

Figure 14. Axial and radial profiles for the organic phase with one impeller as functions of elevation $h$ and radial positions at total liquid depth $\mathrm{H} 4$ and impeller speeds 528, 686, 844, and $1000 \mathrm{rpm}$. 


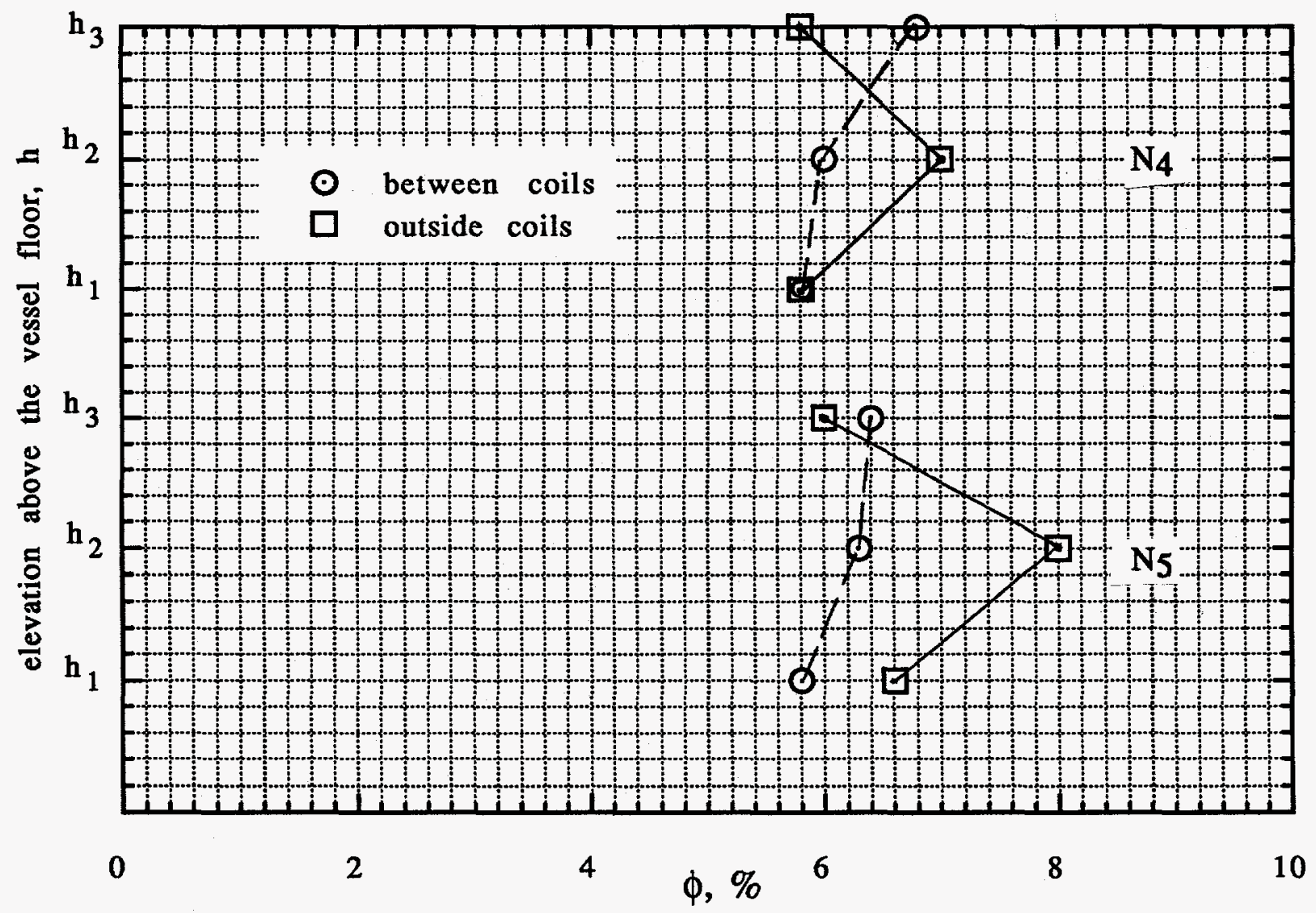

Figure 15. Axial and radial concentration profiles for the organic phase with two impellers as functions of elevation and radial positions at total liquid height $\mathrm{H} 5$ and impellers speeds 528 and $686 \mathrm{rpm}$. 


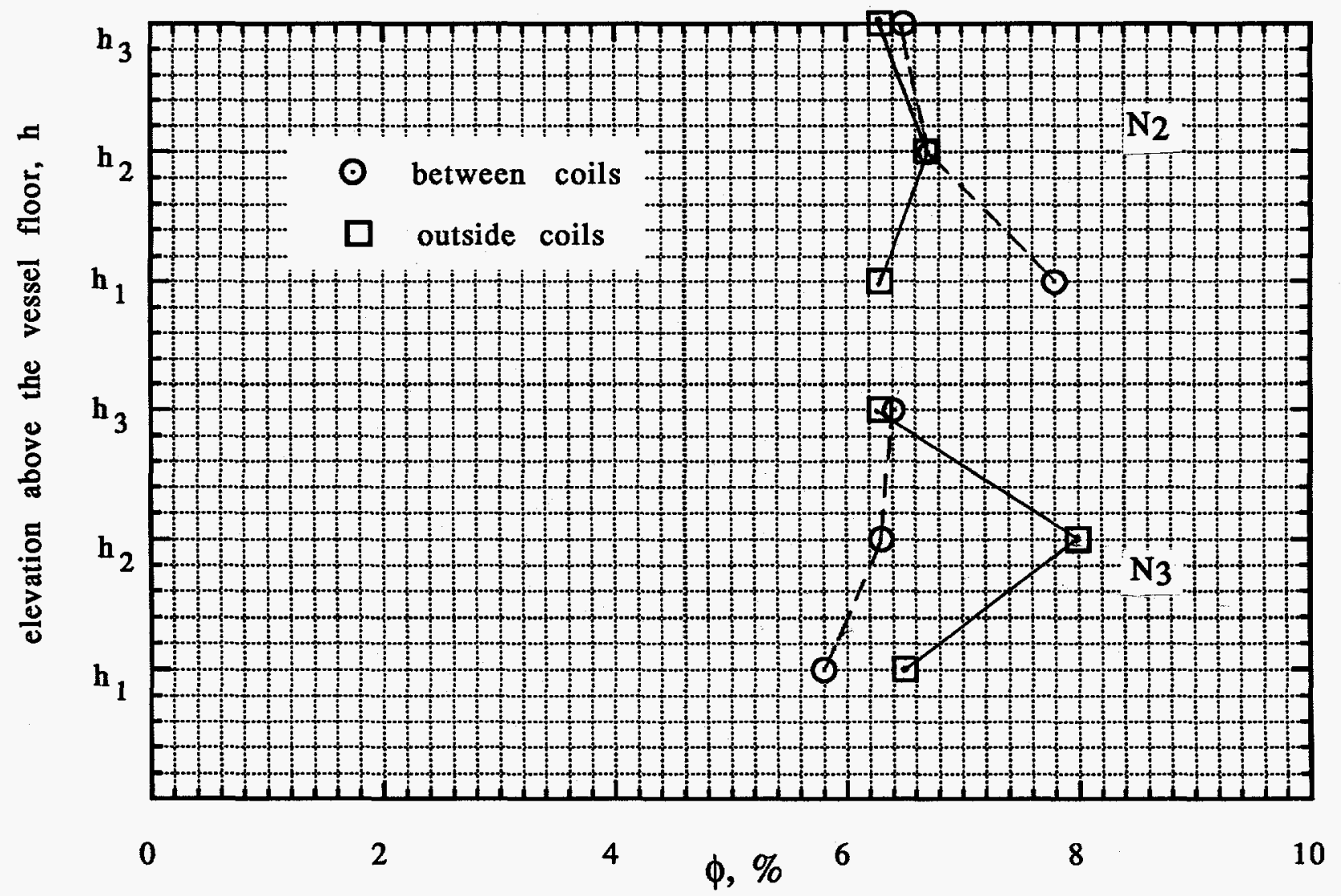

Figure 16. Axial and radial concentration profiles for the organic phase with two impellers as functions of elevation and radial positions at total liquid height $\mathrm{H} 5$ and impellers speeds 844 and $1000 \mathrm{rpm}$ 


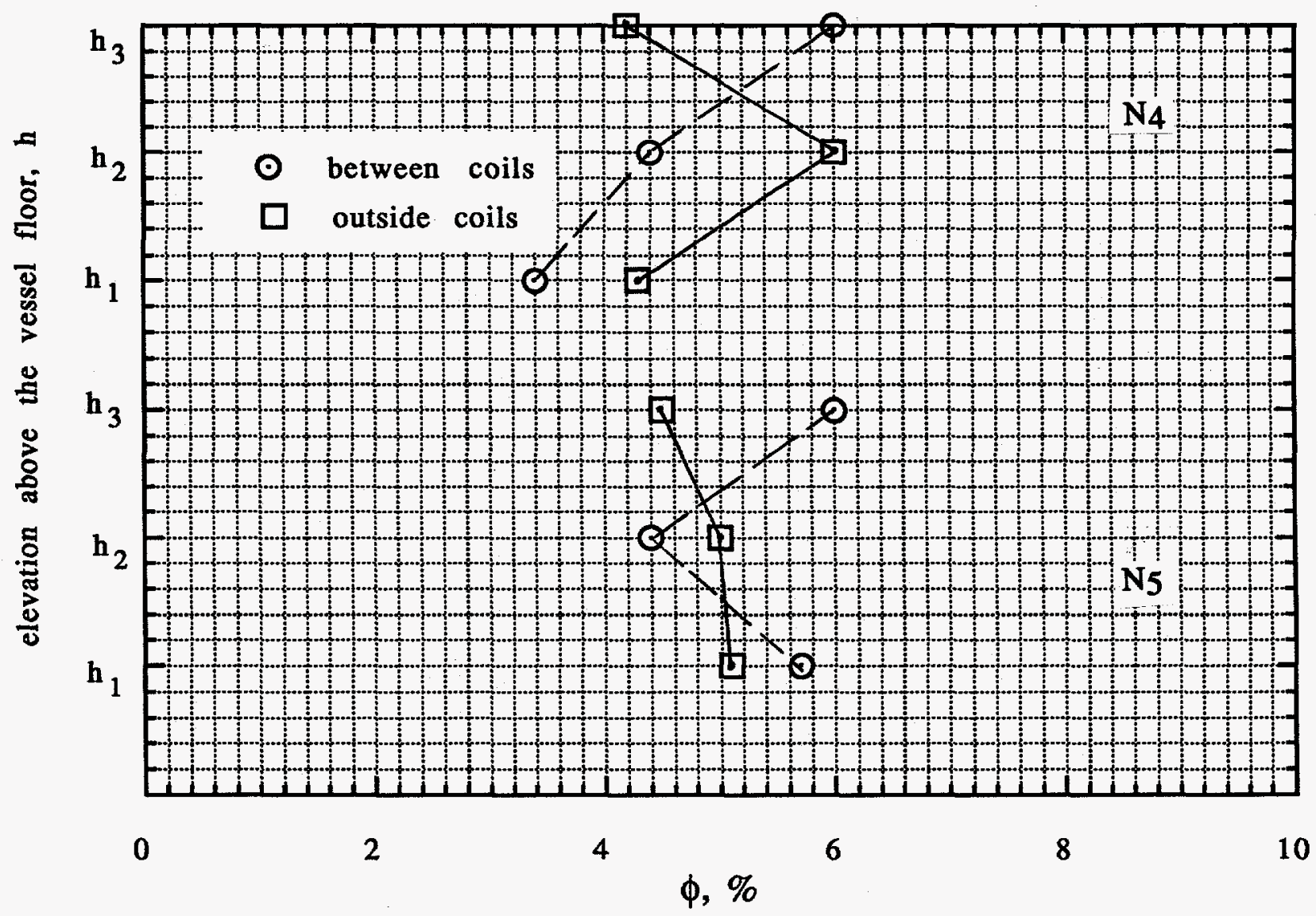

Figure 17. Axial and radial concentration profiles for the organic phase with two impellers as functions of elevation and radial positions at total liquid height $\mathrm{H} 6$ and impellers speeds 528 and $686 \mathrm{rpm}$ 